\title{
Behaviour of the ocean DMS(P) pools in the Sargasso Sea viewed in a coupled physical- biogeochemical ocean model ${ }^{1}$
}

\author{
Yvonnick Le Clainche, Maurice Levasseur, Alain Vézina, John W.H. Dacey, \\ and François J. Saucier
}

\begin{abstract}
The dimethylsulfide (DMS) production model NODEM (Northern Oceans DMS Emission Model) was coupled with the water column ocean model GOTM (General Ocean Turbulence Model) that includes a two-equation $k-\varepsilon$ turbulence scheme. This coupled physical-biogeochemical ocean model represents a significant improvement over the previous uncoupled version of NODEM that was driven by a diagnostic vertical mixing scheme. Using the same set of biogeochemical parameters, the coupled model is used to simulate the annual cycles of 1992 and 1993 at Hydrostation $\mathrm{S}$ in the Sargasso Sea. The better reproduction of the turbulent mixing environment corrects some deficiencies in nitrogen cycling, especially in the seasonal evolution of the nutrient concentrations. Hence, the coupled model captures the late-winter chlorophyll- and DMS(P)-rich blooms. It is also more adept at reproducing the vertical distribution of chlorophyll and DMS(P) in summer. Moreover, the DMS pool becomes less dependent on parameters controlling the nitrogen cycle and relatively more sensitive to parameters related to the sulfur cycle. Finally, the coupled model reproduces some of the observed differences in DMS(P) pools between 1992 and 1993, the latter being an independent data set not used in calibrating the initial version of NODEM.
\end{abstract}

Résumé : Le modèle NODEM (« Northern Oceans DMS Emission Model ») de production de dimethylsulfide (DMS) a été couplé avec le modèle 1-D d'océan GOTM («General Ocean Turbulence Model»), qui inclue un schéma de la turbulence océanique du second ordre de type $k-\varepsilon$. Ce modèle couplé physique et biogéochimique constitue une amélioration significative de la précédente version non couplée de NODEM, qui s'appuyait sur un schéma diagnostique pour le mélange vertical. Reprenant les mêmes paramètres biogéochimiques, le modèle couplé a été utilizé pour simuler le cycle saisonnier des années 1992 et 1993 à la station S en mer des Sargasses. La meilleure prise en compte de l'aspect turbulent du mélange océanique corrige certains défauts dans la représentation du cycle de l'azote, en particulier l'évolution saisonnière des concentrations en nutriments. Le modèle couplé capture maintenant les floraisons phytoplanctoniques de fin d'hiver et les pics en chlorophylle et en DMS(P) qui les caractérisent. Il améliore également la représentation des distributions verticales de chlorophylle et de DMS(P) en été. De plus, le réservoir de DMS est moins dépendant des paramètres contrôlant le cycle de l'azote, et relativement plus sensible aux paramètres reliés au cycle du souffre. Finalement, le modèle couplé reproduit certaines des différences observées entre 1992 et 1993 dans les réservoirs de $\mathrm{DMS}(\mathrm{P})$, la dernière année constituant un jeu de données indépendant qui n'a pas été utilizé pour la calibration de la version initiale de NODEM.

\section{Introduction}

Dimethylsulfide (DMS) is the most abundant form of volatile organic sulfur in the ocean. It results from the enzymatic cleavage of dimethylsulfoniopropionate (DMSP) (Malin and Kirst 1997), which is an organic sulfur compound produced by many phytoplankton species (Keller 1989). The ventilation of DMS is the largest known natural source of atmospheric sulfur (Bates et al. 1992; Andreae and Crutzen 1997). The most recent estimates (Kettle and Andreae 2000)

Received 24 March 2003. Accepted 20 November 2003. Published on the NRC Research Press Web site at http://cjfas.nrc.ca on 23 June 2004.

$\mathrm{J} 17406$

Y. Le Clainche ${ }^{2}$ and M. Levasseur. Québec-Océan, Département de Biologie, Université Laval, Pavillon Alexandre-Vachon, Québec, QC G1K 7P4, Canada.

A. Vézina. Fisheries and Ocean Canada, Bedford Institute of Oceanography, Dartmouth, NS B2Y 4A2, Canada.

J.W.H. Dacey. Department of Biology, Woods Hole Oceanographic Institution, Redfield 3 MS32, Woods Hole, MA 02543, U.S.A.

F.J. Saucier. Fisheries and Ocean Canada, Maurice Lamontagne Institute, 850 route de la Mer, Mont-Joli, QC G5H 3Z4, Canada.

${ }^{1}$ This paper is part of the proceedings of the Third International Symposium on Biological and Environmental Chemistry of DMS(P) and Related Compounds, held in Rimouski (Québec), 26-28 September 2002.

${ }^{2}$ Corresponding author (e-mail: yvonnick.leclainche@ giroq.ulaval.ca). 
of DMS emission from the world's ocean range from $15 \times$ $10^{12}$ to $33 \times 10^{12} \mathrm{~g} \mathrm{~S} \cdot \mathrm{year}^{-1}$, about one-third of global anthropogenic sulfur emissions (Rodhe 1999). Because the residence time of DMS sulfur in the atmosphere is longer than that of anthropogenic sulfur, marine DMS emissions contribute approximately $40 \%$ of the global atmospheric sulfur burden (Chin and Jacob 1996). However, sea surface DMS concentrations and emissions show wide variations over time and space (Kettle and Andreae 2000), which result from complex biological cycling in a highly dynamical physical environment.

In the marine atmosphere, DMS is oxidized to form nonsea-salt sulfate and methanesulfonate aerosols (Andreae and Crutzen 1997), which affect the radiative balance of the earth. These aerosols can have direct effects by absorbing and reflecting incoming solar radiation (Mitchell et al. 1995). They can also have indirect effects by acting as cloud condensation nuclei, thereby changing the microphysical properties of clouds, in particular increasing their albedo (Falkowski et al. 1992; Clarke et al. 1998). Consequently, DMS emissions may have a cooling effect on climate that partly counteracts the warming effect of greenhouse gases. Moreover, Charlson et al. (1987) have postulated that an increase in solar irradiance makes phytoplankton produce more DMS. They have proposed a negative feedback between oceanic DMS and climate involving DMS emission cloud condensation nuclei - cloud albedo - solar radiation temperature. Both empirical analysis (Foley et al. 1991; Lawrence 1993) and regional (Gabric et al. 1998, 2001) and global (Bopp et al. 2003) modeling studies to assess this DMS-climate feedback have shown a small but nonnegligible negative feedback on warming. Nevertheless, the hypothesis formulated by Charlson et al. (1987), known as the CLAW hypothesis, is still under investigation, since the response of DMS production in surface waters to modifications of climatic factors is not understood (Simó 2001).

The first-order impact of climate change will be on airsea heat fluxes, temperature, wind stress, and consequently the stratification of the upper ocean (Houghton et al. 2001). Mixing in the upper ocean depends strongly on wind and temperature and controls marine ecosystem dynamics (Mann and Lazier 1991), including the biogenic production and vertical distribution of particulate DMSP $\left(\mathrm{DMSP}_{\mathrm{p}}\right)$ and DMS (e.g., Simó and Pedrós-Alió 1999; Jodwalis et al. 2000; Simó et al. 2002). Clearly, short-duration events in the ecosystem at low levels are very important and depend critically on the accurate representation of turbulent quantities such as the depth of the mixed layer and temperature to understand the ocean DMS production and its response to climate change.

We have developed a one-dimensional DMS production model based on an ecosystem model. This model, called NODEM for Northern Oceans DMS Emission Model (Lefèvre et al. 2002), has been calibrated in the Sargasso Sea using measured time series of DMS(P) collected in 1992 at Hydrostation $\mathrm{S}\left(32^{\circ} 10^{\prime} \mathrm{N}, 64^{\circ} 30^{\prime} \mathrm{W}\right)$ by Dacey et al. (1998). The vertical diffusivity profiles needed to run this model were computed by a direct parameterization (Denman and Gargett 1983). This diagnostic approach used semimonthly density profiles observed at BATS station $\left(31^{\circ} 50^{\prime} \mathrm{N}\right.$, $64^{\circ} 10^{\prime} \mathrm{W}$ ) and linearly interpolated for each day of 1992 and winds recorded at the Bermuda airport weather station. This type of parameterization cannot reproduce adequately the dynamics of the mixed layer, especially its response to rapid changes in atmospheric forcing.

To investigate the impact of ocean physics on DMS production, we constructed a one-dimensional coupled physical-biogeochemical ocean model by coupling NODEM with GOTM (General Ocean Turbulence Model) (Burchard et al. 1999; http://www.gotm.net), a water column ocean model that includes a two-equation turbulence parameterization scheme. The different components of the coupled GOTM-NODEM model are described in the next section. The main goal of this study was to validate this new coupled model. Thus, we performed a new simulation at the Hydrostation S site for 1992, comparable with the previous one performed with the uncoupled version of NODEM (Lefèvre et al. 2002). We used the same set of parameters that were adjusted in the 1992 uncoupled simulation. But the vertical turbulent exchange processes are now simulated by GOTM accordingly to its second-order turbulent closure scheme. This allows the examination of the impact of this more realistic representation of vertical mixing on the NODEM predictions of $\mathrm{DMS}(\mathrm{P})$ concentrations for 1992. We also conducted the same parametric sensitivity analysis as in the uncoupled version of NODEM to estimate the impact of wind-induced turbulence on the $\operatorname{DMS}(\mathrm{P})$ pools simulated. Finally, we validated NODEM on a second complete annual cycle (1993), independent of the annual cycle used to calibrate the initial NODEM model.

\section{Description of the coupled model}

\section{Physical ocean model}

GOTM is a one-dimensional numerical model of the ocean water column that implements a number of standard turbulence closure schemes for accurate simulation of vertical turbulent exchange processes in the marine environment (Burchard et al. 1999; http://www.gotm.net). For this study, we chose the widely used $k-\varepsilon$ turbulence closure scheme (Burchard and Baumert 1995; Burchard and Petersen 1999). The turbulent kinetic energy $k$ and the dissipation rate $\varepsilon$ are calculated via prognostic equations, which consider turbulence generation by wind, buoyancy, and shear productions, as well as dissipation and turbulent diffusion. These equations can be found in the reference GOTM technical report (Burchard et al. 1999).

It is assumed that all tracers (temperature, nutrients, phytoplankton, etc.) have the same eddy diffusivity $v_{t}$, which is based on the assumption of fully developed turbulence. The eddy diffusivity $v_{t}$ is function of the turbulent kinetic energy $k$, the normalized dissipation rate $\varepsilon$, and a nondimensional stability function $c_{\mu}$ that is calculated following the method of Kantha and Clayson (1994). We use also the parameterization derived from Large et al. (1994) to promote increased mixing induced by shear instability and internal wave activity under stably stratified situations (Kantha and Clayson 1994), such as summer conditions in the Sargasso Sea. When $k$ becomes smaller than $10^{-6} \mathrm{~m}^{2} \cdot \mathrm{s}^{-2}$ (diagnostic for stable stratification), the eddy diffusivity $v_{t}$ is calculated as the sum of a shear-induced diffusivity $v_{t}^{S I}$ (modeled as a 
Fig. 1. Schematic view of the NODEM model structure. The black boxes represent the six nitrogen compartments of the model and the solid black arrows indicate the nitrogen fluxes among these compartments. The shaded ellipses represent the three sulfur pools (the DMSP $_{\mathrm{p}}$ pool is included in phytoplankton). The two additional trapezoids illustrate free sulfate (S) and dimethyl sulfoxide (DMSO), which represent sinks for DMS and $\mathrm{DMSP}_{\mathrm{d}}$. The shaded arrows indicate the sulfur fluxes among the five sulfur pools. The shaded broken arrows illustrate the influence of physical factors.

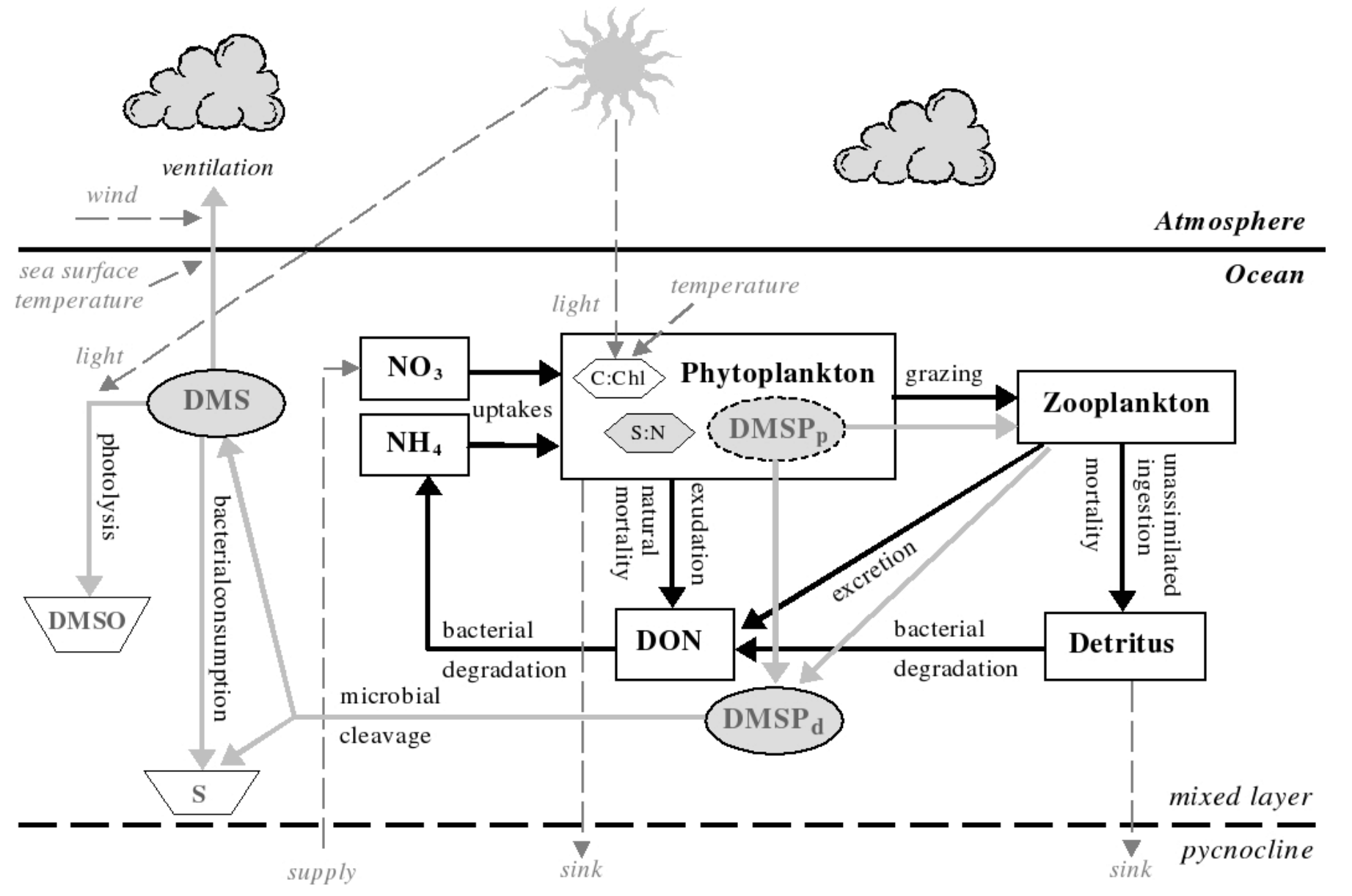

strongly decreasing function of the Richardson number gradient) and a constant internal wave-induced diffusivity $v_{t}^{\text {IW }}$ $\left(10^{-4} \mathrm{~m}^{2} \cdot \mathrm{s}^{-1}\right.$ for tracers $)$.

\section{Ecosystem and DMS $(P)$ cycle model}

NODEM is an ecosystem model based on nitrogen fluxes that also simulates the DMS(P) cycle. Its initial uncoupled version is discussed in detail in Lefèvre et al. (2002). For the coupling with the physical ocean model, two distinct modules for the ecosystem and the DMS(P) cycle have been integrated into the modular structure of GOTM. The ecosystem module computes primary production and the nitrogen fluxes among six compartments: phytoplankton, microzooplankton, detritus, dissolved organic nitrogen (DON), ammonium $\left(\mathrm{NH}_{4}{ }^{+}\right)$, and nitrate $\left(\mathrm{NO}_{3}{ }^{-}\right)$. The DMS(P) cycle module simulates three sulfur components: $\mathrm{DMSP}_{\mathrm{p}}$, dissolved DMSP $\left(\mathrm{DMSP}_{\mathrm{d}}\right)$, and DMS. The scheme presented sums up the main characteristics of the NODEM model (Fig. 1).

The biogeochemical tracers are introduced in GOTM using the general equation

$$
\frac{\partial X}{\partial t}-\frac{\partial}{\partial z}\left(X w+v_{t} \frac{\partial X}{\partial z}\right)=P(X)-S(X)
$$

For a tracer $X$, the turbulent flux $v_{\mathrm{t}} \frac{\partial X}{\partial z}$ is calculated as the product of the eddy diffusivity $v_{t}$ with the vertical gradient of this tracer. The vertical movement of the tracer (e.g., sedimentation) is related to the vertical velocity $w$. The terms $P(X)$ and $S(X)$ on the right-hand side of the equation represent the sum of the production sources and the sum of the sinks, respectively. The complete equations for all of the state variables implemented in NODEM are presented in Appendix A. Thereafter, we recall the main characteristics of NODEM, which is fully described in Lefèvre et al. (2002).

The primary production computed by the ecosystem module is controlled by $(i)$ photosynthetically available radiation, (ii) $\mathrm{NO}_{3}{ }^{-}$availability determined by vertical mixing from below (new production), (iii) $\mathrm{NH}_{4}{ }^{+}$remineralized in the euphotic zone (regenerated production), and (iv) ambient water temperature. The underwater light field in the euphotic zone that is used to compute the photosynthetic activity is calculated from 400-700 $\mathrm{nm}$ by a spectral module (Sathyendranath and Platt 1988). The model assumes that, in oligotrophic waters like in Bermuda, most of the mortality is due to microzooplankton grazing, whereas natural mortality resulting from cell lysis represents a minor contribution (Bissett et al. 
1994). Dead phytoplankton is instantaneously routed to the dissolved pool assuming that cell lysis occurs rapidly. The grazing function assumes a high affinity of microzooplankton for phytoplankton (Bissett et al. 1994), that is, maximal grazing rates are obtained at low phytoplankton concentrations (low half-saturation constant). The unassimilated part (30\%) of the ingested nitrogen (Doney et al. 1996) is channeled to the detritus pool. Microzooplankton nitrogen is lost through mortality (sum of predation and export) to the detritus pool and excretion to the DON pool. Sloppy feeding (dissolved organic matter release by cell rupture during grazing) is considered to be included in the excretion rate (Fasham et al. 1990). Detrital nitrogen and DON are remineralized to DON and $\mathrm{NH}_{4}{ }^{+}$, respectively.

DMSP $_{\mathrm{p}}$ is produced by phytoplankton proportionally to primary production through the $\mathrm{S}_{\mathrm{DMSP}}: \mathrm{N}$ cell quota that varies with time and depth (see below). Three processes lead to the release of $\mathrm{DMSP}_{\mathrm{d}}$ in the water: phytoplankton cell lysis, phytoplankton exudation, and microzooplankton excretion. Potential release of $\mathrm{DMSP}_{\mathrm{d}}$ by cells rupturing during feeding is included in our excretion term. In the absence of information about the exudation of DMSP relative to that of DON, the exudation rate for DMSP is set as the same as for DON. It is assumed that all of the $\mathrm{DMSP}_{\mathrm{p}}$ grazed by microzooplankton is excreted directly to the dissolved pool (Lefèvre et al. 2002). Thus, there is no accumulation of $\mathrm{DMSP}_{\mathrm{p}}$ into microzooplankton or into detritus produced by microzooplankton. $\mathrm{DMSP}_{\mathrm{d}}$ undergoes microbial degradation either to DMS or to other sulfur compounds ("S" sink on Fig. 1). The microbial DMS yield (percentage of $\mathrm{DMSP}_{\mathrm{d}}$ cleaved to DMS) is set at $40 \%$ and includes both bacterial and algal conversion. Finally, DMS is lost through bacterial consumption, photolysis, and ventilation to the atmosphere.

We used the same set of parameters for both nitrogen and sulfur cycling, which were adjusted in the 1992 uncoupled simulation. They are fully discussed in Lefèvre et al. (2002) and are summed up in Appendix A (Table A1).

\section{Seasonal variations of parameters}

The initial work with the uncoupled NODEM (Lefèvre at al. 2002) found it necessary to impose seasonal and depth variations on some key parameters to reproduce the main characteristics of the chlorophyll $a$ (Chl $a$ ) (Michaels and Knap 1996) and DMS(P) data (Dacey et al. 1998) in the Sargasso Sea. This approach was retained in the coupled model. The varying parameters are the phytoplankton cell and detritus sinking rates, the $\mathrm{C}: \mathrm{Chl}$ cell ratio, and the $\mathrm{S}_{\mathrm{DMSP}}: \mathrm{N}$ cell ratio. Their variations aim to simulate the influence of seasonal change in phytoplankton composition. In winter and early spring, when vertical mixing enhances the supply of nutrients, the phytoplankton community is dominated by larger algae (higher sinking rates), which are characterized by low $\mathrm{C}$ : $\mathrm{Chl}$ ratio and low $\mathrm{S}_{\mathrm{DMSP}}: \mathrm{N}$ quota. In the summer stratified and stable waters, the phytoplankton community is dominated by smaller algae (lower sinking rates), which are characterized by higher $\mathrm{C}: \mathrm{Chl}$ ratio and $\mathrm{S}_{\mathrm{DMSP}}: \mathrm{N}$ quota.

In agreement with the modeling study at BATS of Hurtt and Amstrong (1996), the phytoplankton cells and detritus sinking rates used in NODEM were kept very low throughout the year. However, they vary from 0.01 to $0.1 \mathrm{~m} \cdot \mathrm{day}^{-1}$ and from 0.02 to $0.2 \mathrm{~m} \cdot \mathrm{day}^{-1}$, respectively, and are keyed to the zenithal angle of the sun. In accord with the observations of Malone et al. (1993), the C:Chl cell ratio is forced to vary in surface waters from 50 to $100 \mathrm{mg} \mathrm{C} \cdot \mathrm{mg} \mathrm{Chl}^{-1}$. This variation follows a sinusoidal function throughout the year, also based on the zenithal angle of the sun. The DMSP quota is known to vary not only among species (Keller 1989) but also with environmental forcing like nutrient availability (Keller et al. 1999). In the model, the surface $S_{\mathrm{DMSP}}: \mathrm{N}$ quota varies from 0.1 to $0.5 \mathrm{mg} \mathrm{S} \cdot \mathrm{mg} \mathrm{N}^{-1}$ based on a linear function of the surface irradiance at noon, which is highly variable from day to day. For the depth dependence, both the $\mathrm{C}$ :Chl ratio and the $\mathrm{S}_{\mathrm{DMSP}}: \mathrm{N}$ quota follow the underwater extinction of the irradiance. As mentioned in Lefèvre et al. (2002), the calibration is based on in situ measurements of $\mathrm{S}_{\mathrm{DMSP}}$ :Chl ratio at Hydrostation S from the 1992 data set of Dacey et al. (1998) and from the NODEM II cruise (Scarratt et al. 2002). The $\mathrm{C}$ : Chl cell ratio converges to $20 \mathrm{mg} \mathrm{C} \cdot \mathrm{mg}$ $\mathrm{Chl}^{-1}$ at the bottom of the euphotic zone $(\sim 140 \mathrm{~m})$ and the $\mathrm{S}_{\text {DMSP }}: \mathrm{N}$ quota converges to $0.1 \mathrm{mg} \mathrm{S} \cdot \mathrm{mg} \mathrm{N}^{-1}$. These ranges of variation are unchanged for the simulation of the independent year 1993. We show seasonal mean profiles of the two ratios calculated for January-February-March, AprilMay-June, July-August-September, and October-NovemberDecember of year 1992 in Fig. 2.

The complete formulations for the seasonal variation at the surface and for the variations with depth can be found in Lefèvre at al. (2002). The extreme annual values for the zenithal angle of the sun depend only on geographical location. In contrast, the extreme annual values for the surface irradiance at noon change slightly $(<10 \%)$ from year to year. They were determined for each year by a standalone run of the radiation spectral model.

\section{Technical characteristics of the simulation}

\section{Numerics}

Because the focus is on the dynamics within the mixed layer, only the first $250 \mathrm{~m}$ of the water column are considered. The vertical discretization is regular with 250 layers of $1 \mathrm{~m}$ thickness from the surface to $250 \mathrm{~m}$ depth. A further simulation extending over $500 \mathrm{~m}$ with 500 vertical levels of $1 \mathrm{~m}$ thickness was also performed. Its results, both for the physics and for the ecosystem and the DMS cycle, are identical to the results presented in this study. The vertical resolution is the same for the physical mean flow ( $u, v$, temperature, and salinity) and the biogeochemical (phytoplankton, microzooplankton, detritus, $\mathrm{DON}, \mathrm{NH}_{4}^{+}, \mathrm{NO}_{3}{ }^{-}$, $\mathrm{DMSP}_{\mathrm{p}}, \mathrm{DMSP}_{\mathrm{d}}$, and DMS) variables. At each vertical level, they represent the mean value for the $1-\mathrm{m}$ vertical interval and are thus determined at the centres of the interval. The turbulent quantities $\left(k, \varepsilon, v_{t}\right.$, and $\left.c_{\mu}\right)$ are discretized on the same grid but are positioned at the interface of the intervals.

The simple diffusion equation (general eq. 1) for a mean flow quantity such as tracers is fully implicitly discretized over two time levels. This leads for each transport equation to a system of linear equations with a tridiagonal matrix, which is solved by means of the simplified Gaussian elimination (see GOTM report (Burchard et al. 1999; http://www. gotm.net) for a complete description). This calculation is done in the general transport module of GOTM. The main 
Fig. 2. Seasonal mean profiles for January-February-March (JFM), April-May-June (AMJ), July-August-September (JAS), and October-November-December (OND) 1992 for (a) C:Chl ratio and (b) $\mathrm{S}_{\mathrm{DMSP}}: \mathrm{N}$ quota as simulated by the coupled model.
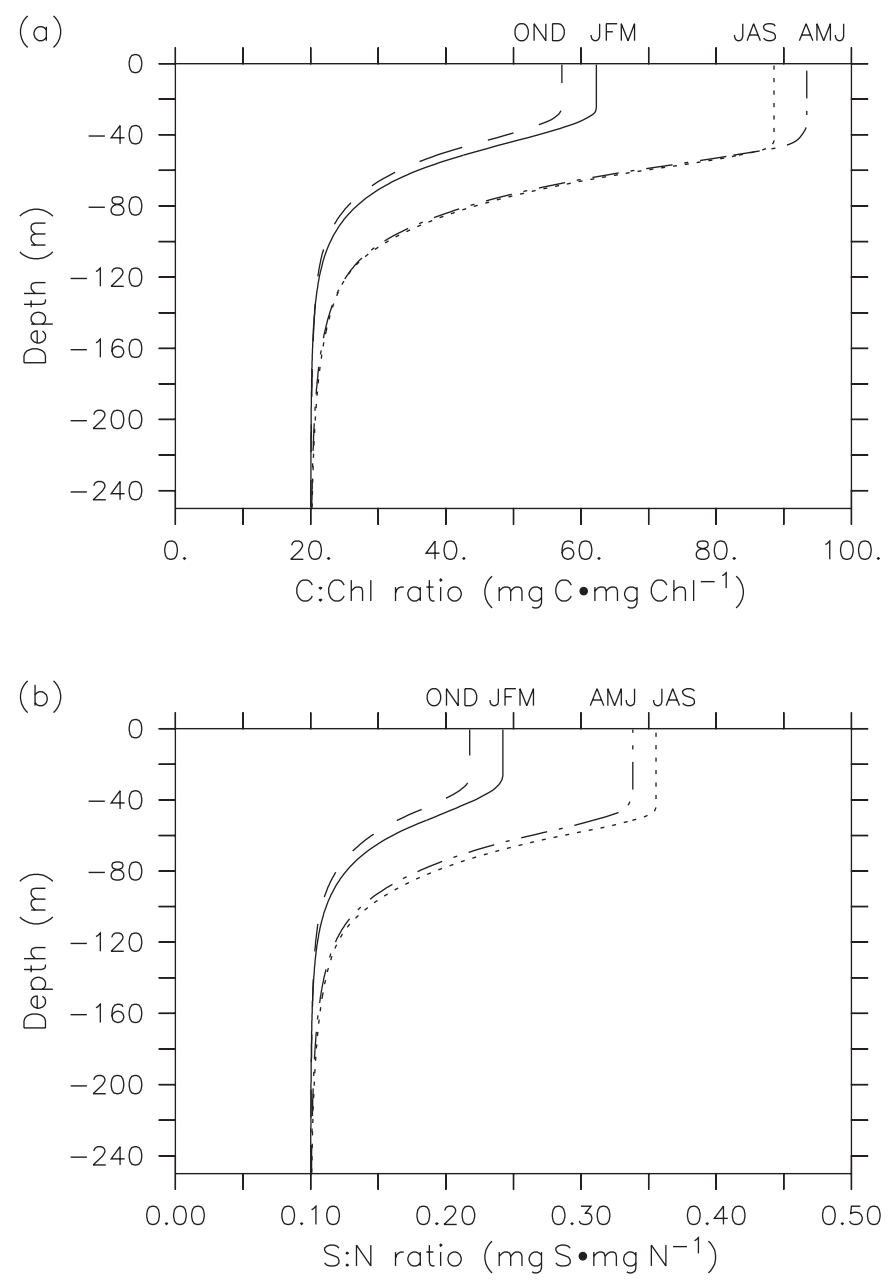

time step for the physics (hydrodynamic equations, temperature and salinity equations, turbulence equations) is $15 \mathrm{~min}$. The time step for the biological processes (primary production and nitrogen fluxes) and the processes involved in the $\operatorname{DMS}(\mathrm{P})$ cycle is $1 \mathrm{~h}$. Thus, the source and sink terms (see Appendix A) for each of the biogeochemical variables are computed every four physical time steps. Each calculated budget is directly added to the appropriate variable, independently of the transport equation. However, all of these variables undergo vertical turbulent mixing and sinking (for phytoplankton and detritus) every physical time step (i.e., $15 \mathrm{~min}$ ). Their transport equations are thus resolved by the general transport module according to zero on the right-hand side of the equation.

The simulation starts on 1 January 1991 and ends on 31 December 1993. Whereas the spinup of the ocean occurs rapidly (on turbulent time scales), the ecosystem model takes a few months to reach near steady state. Thus, the first year is discarded and we concentrate on the solutions for the years 1992 and 1993. This approach differs from the previous uncoupled simulation of NODEM (Lefèvre et al. 2002), where the solution for 1992 was obtained after 2 years of setup with the same 1992 forcing.

\section{Surface forcing and bottom boundary conditions}

The wind stresses are calculated through a bulk formula using the daily mean wind velocity components (at $10 \mathrm{~m}$ height) given by the NCEP-CDAS reanalysis (Kalnay et al. 1996). The wind is prescribed as a surface boundary condition for the momentum equations.

The net heat flux is split into two components: the shortwave incident solar radiation (reduced by the sea surface albedo) and the nonsolar heat flux including the contributions of the latent, sensible, and infrared radiation. The nonsolar heat flux is considered as a boundary condition at the surface and is calculated through a bulk formula as a function of the sea surface temperature (prognostic), the relative humidity, the air temperature (at $2 \mathrm{~m}$ height), the surface air pressure, and the cloud fraction. The daily mean values of the meteorological fields come from the NCEP-CDAS reanalysis (Kalnay et al. 1996). The solar flux is a source term in the temperature equation. A radiation spectral model (Sathyendranath and Platt 1988), already used in the previous uncoupled NODEM simulation, is called by GOTM to compute the surface irradiance and underwater spectral light field from 400 to $700 \mathrm{~nm}$. The spectral model also requires the mean wind speed, the relative humidity, the air temperature, and the cloud fraction. To calculate the impact of aerosols in the Sargasso Sea, the air mass type is set to the maritime tropical one and the horizontal visibility length scale is fixed to $20 \mathrm{~km}$.

The freshwater flux through the surface is not considered in the salinity equation (see below). At the bottom boundary, only the $\mathrm{NO}_{3}^{-}$concentration is fixed to its initial value of $40 \mathrm{mg} \mathrm{N} \cdot \mathrm{m}^{-3}\left(2.8 \mathrm{mmol} \cdot \mathrm{m}^{-3}\right)$ from BATS data (Michaels and Knap 1996). As confirmed by the further simulation extending over $500 \mathrm{~m}$, the bottom boundary conditions have no influence on the euphotic zone (approximately top $150 \mathrm{~m}$ ), which represents our main domain of interest.

\section{Control of the physical model}

The sea surface salinity and the sea surface temperature are restored every day towards daily data interpolated from the Hydrostation S data set (obtained via http://www.bbsr. edu) reported in Knap et al. (1993, 1994, 1995, 1997). The sea surface salinity relaxation replaces the effect of the surface freshwater flux, which is more accurate than attempting to specify freshwater flux. The sea surface temperature relaxation corresponds to a first-order Taylor expansion of the total surface net heat flux around sea surface temperature and acts as a flux correction.

The depth profiles of salinity and temperature from the Hydrostation S data set, interpolated both in time (to obtain daily profiles) and over depth (to obtain vertical profiles at 1-m resolution), are also used to control the physical model. The restoring towards temperature and salinity observations on the whole water column $(250 \mathrm{~m})$ is done with a relaxation time constant of 10 days. This diagnostic method accounts for the effects of lateral fluxes of heat and salt (via horizontal advection/diffusion) that cannot be represented explicitly by one-dimensional models.

\section{Initialization}

The physical model is initialized with temperature and salinity profiles for 1 January 1991, interpolated from the data 
set at Hydrostation $\mathrm{S}$. The initial $\mathrm{NO}_{3}{ }^{-}$concentration profile is taken from BATS data (Michaels and Knap 1996). The phytoplankton concentration is set to $1 \mathrm{mg} \mathrm{N} \cdot \mathrm{m}^{-3}$ from surface to $150 \mathrm{~m}$ depth and $0.1 \mathrm{mg} \mathrm{N} \cdot \mathrm{m}^{-3}$ below. The microzooplankton is set to $0.1 \mathrm{mg} \mathrm{N} \cdot \mathrm{m}^{-3}$ from surface to $150 \mathrm{~m}$ depth and $0.01 \mathrm{mg} \mathrm{N} \cdot \mathrm{m}^{-3}$ below. The $\mathrm{DMSP}_{\mathrm{p}}$ concentration is set to $0.1 \mathrm{mg} \mathrm{S} \cdot \mathrm{m}^{-3}$ from surface to $150 \mathrm{~m}$ depth and $0.01 \mathrm{mg} \mathrm{S} \cdot \mathrm{m}^{-3}$ below following the phytoplankton profile according to a constant $\mathrm{S}: \mathrm{N}$ ratio of $0.1 \mathrm{mg} \mathrm{S} \cdot \mathrm{mg} \mathrm{\textrm {N } ^ { - 1 }}$. The $\mathrm{DMSP}_{\mathrm{d}}$ and DMS concentrations, as well as all of the others variables, are set to zero. Tests with different initial conditions have showed no sensitivity.

\section{Results and discussion}

The annual cycles of upper ocean temperature (from the surface to $250 \mathrm{~m}$ depth) simulated by GOTM for 1992 and 1993 are shown in Fig. 3b. The temperature data from Hydrostation S (Knap et al. 1993, 1994, 1995, 1997), interpolated to the model grid and for each day, are shown for comparison in Fig. 3c. Not surprisingly, given the use of relaxation, the simulated temperature structures of the upper ocean for both 1992 and 1993 are close to the observed structures. In contrast with the classic diagnostic of the mixed layer depth based on the $0.5{ }^{\circ} \mathrm{C}$ temperature deviation from the surface temperature (used in Lefèvre et al. 2002), the turbulent mixed layer depth is defined as the depth where turbulent kinetic energy decreases to less than $10^{-6} \mathrm{~m}^{2} \cdot \mathrm{s}^{-2}$ (the solid line in Fig. $3 b$ indicates that depth). This approach provides a dynamically based view of the mixed layer variability and better visualizes the short-term mixing events related to the high variability of the wind forcing (shown in parallel in Fig. 3a).

\section{Impact of prognostic turbulent mixed layer modeling on the NODEM simulation (1992)}

The coupled model simulates two deep vertical mixing events during winter 1992 in mid-February and at the end of March (Fig. 3b). Strong winds induce significant mixing below the nitracline, producing an input of nutrients in the upper ocean from depth (Fig. 4a). Primary production is enhanced and two short phytoplankton blooms develop (Fig. 5b). This pattern is in good agreement with the observations of Chl $a$ (Fig. 5a) at the Bermuda BATS station near Hydrostation S (Michaels and Knap 1996). Because we use winds from the NCEP reanalysis that are daily means for a relatively large area (grid cell of $1.85^{\circ}$ in longitude and $1.90^{\circ}$ in latitude centred on the position $31.42^{\circ} \mathrm{N}, 63.75^{\circ} \mathrm{W}$ ), the timing of local events cannot be captured very precisely. This may introduce a time lag between the simulated and observed blooms (Fig. 5d). Moreover, simulated Chl $a$ concentrations are overestimated near the bottom of the mixed layer. In contrast, simulated $\mathrm{Chl} a$ concentrations are underestimated in the top $50 \mathrm{~m}$. Because phytoplankton concentration as nitrogen is maximum in the top $50 \mathrm{~m}$ of the water column, this feature may result from the $\mathrm{C}: \mathrm{Chl}$ ratio profile calculated for the winter season. The surface $\mathrm{C}: \mathrm{Chl}$ ratio may be too high, whereas the threshold of $20 \mathrm{mg} \mathrm{C} \cdot \mathrm{mg} \mathrm{Chl}^{-1}$ may be too low at depth. High vertical mixing during this period tends to homogenize phytoplankton community structure in the vertical. The use of the irradiance profile to simu- late the depth variation in $\mathrm{C}$ : Chl may overestimate the vertical structure, as irradiance is not influenced by the mixing.

Nevertheless, the simulation of two winter blooms as observed represents a major improvement compared with the previous uncoupled simulation of NODEM based on a diagnostic mixing model, which was unable to capture the episodic winter nutrient inputs and the associated phytoplankton blooms (Figs. $4 b, 5 c$, and $5 d$ ). On the contrary, the uncoupled NODEM model simulated a constant vertical gradient in the nutrient fields. Without changing any of the ecosystem parameters, the coupling with the ocean turbulence model allows one to reproduce the dynamics of nutrients in winter (Lipschultz 2001). This has repercussions on the $\mathrm{DMSP}_{\mathrm{p}}$ and DMS concentrations simulated during winter. In accordance with the data of Dacey et al. (1998) (Figs. $6 a$ and $7 a$ ), the coupled model simulates a peak of DMSP $\mathrm{Dur}_{\mathrm{p}}$ ing February 1992 (Fig. 6b) followed by an increase in DMS (Fig. 7b). Actually, the observations show two short peaks, but this difference may also result from the inaccuracy of the wind forcing used. As mentioned by Dacey et al. (1998), the peak of $\mathrm{DMSP}_{\mathrm{p}}$ is linked to increases in primary production and phytoplankton biomass, and the rapid response of the DMS pool results from the development of microzooplankton biomass and associated grazing. The coupled model reproduces this dynamic initiated by the deep winter vertical mixing event. This was not captured by the uncoupled NODEM simulation (Figs. $6 c$ and $7 c$ ).

The summer period is characterized by strong stratification and typically a 5- to 20-m deep mixed layer (Fig. 3b). Nutrients show very low surface concentrations (Fig. 4a) and negligible $\mathrm{NO}_{3}{ }^{-}$concentrations in the euphotic zone. The nitrogen cycle is supported by efficient recycling of the dissolved nitrogen pool to $\mathrm{NH}_{4}{ }^{+}$via the microbial loop (Michaels et al. 1994). Thanks to the depth variation of the $\mathrm{C}$ : Chl ratio, the development of a subsurface $\mathrm{Chl}$ maximum near $100 \mathrm{~m}$ was already reproduced in the uncoupled NODEM simulation (Fig. $5 c$ ). But with better resolved mixing into the euphotic zone, the coupled model simulates higher biomass and Chl levels (Fig. $5 b$ ), which are closer to the observations. In agreement with the data of Dacey et al. (1998), it also reproduces the $\mathrm{DMSP}_{\mathrm{p}}$ and DMS subsurface maxima around $40 \mathrm{~m}$ that are well above the $\mathrm{Chl} a$ maximum, in particular during July 1992. In the uncoupled NODEM simulation, the diagnostic model generated not enough vertical mixing under stable conditions. Moreover, this simulation was characterized by unrealistically high concentrations of $\mathrm{NH}_{4}{ }^{+}$, which dominate the nutrient field (Fig. 4b) and stimulate large regenerated production. The rapid turnover prevented an increase of the phytoplankton biomass, but on the other hand, the microzooplankton biomass was enhanced within the mixed layer. Higher concentrations of DMS were thus simulated by the uncoupled version of NODEM in the top $20 \mathrm{~m}$ of the ocean and appeared strongly dependent on the variations of the $\mathrm{S}: \mathrm{N}$ surface ratio. Coupling NODEM with a prognostic turbulent mixing model allows us to correct this weakness of the uncoupled simulation.

Finally, the better parameterization of the turbulent mixing regime and mixed layer depth dynamics affects the dynamics of the nitrogen cycle both in winter and in summer and consequently the variations in the $\mathrm{DMS}(\mathrm{P})$ pools. In comparison with the previous uncoupled NODEM version, 
Fig. 3. Annual cycle for 1992 and 1993 of (a) wind forcing at sea surface from NCEP reanalysis (Kalnay et al. 1996), (b) ocean temperature in the upper $250 \mathrm{~m}$ and turbulent mixed layer depth (solid line added) as simulated by the coupled model, and (c) ocean temperature in the upper $250 \mathrm{~m}$ as interpolated from the Hydrostation $\mathrm{S}$ data set (Knap et al. 1993, 1994, 1995, 1997).

(a)

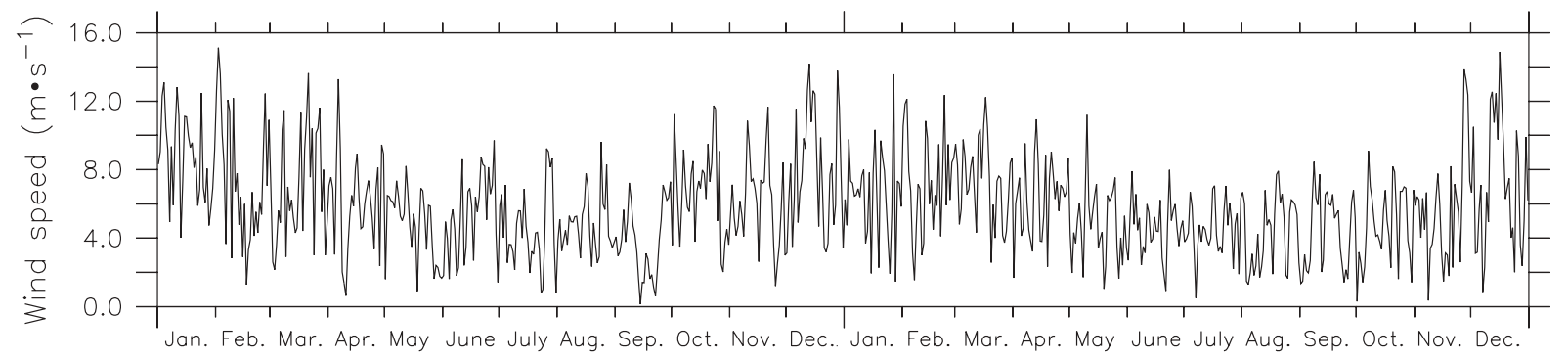

(b)

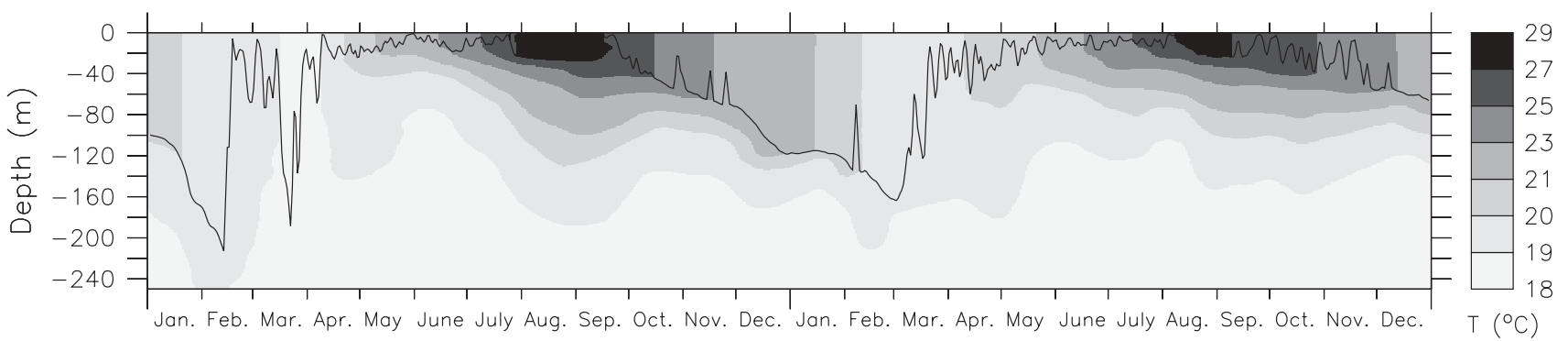

(c)

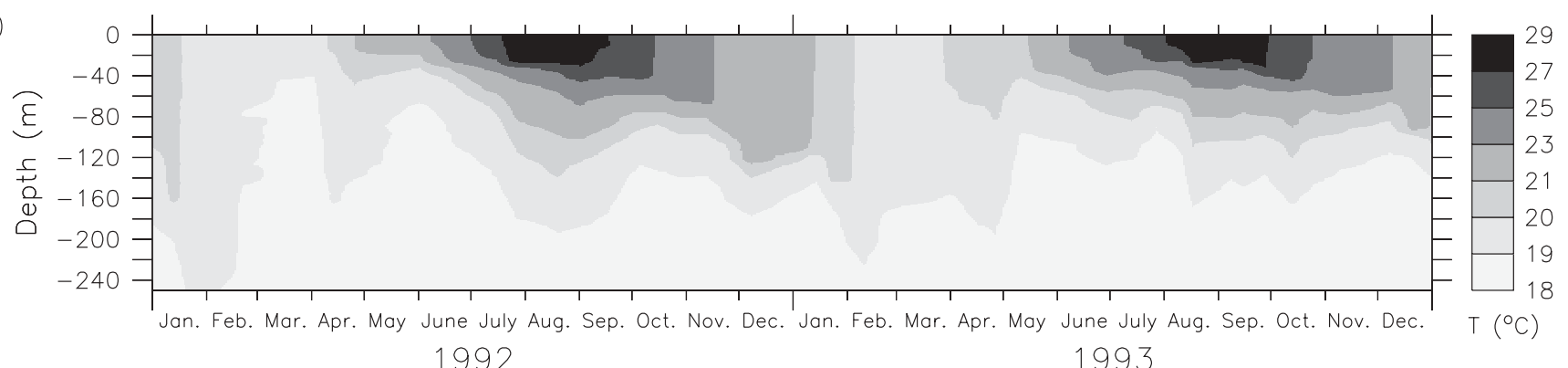

Fig. 4. Annual cycle for 1992 and 1993 of nutrient $\left(\mathrm{NO}_{3}{ }^{-}\right.$and $\left.\mathrm{NH}_{4}{ }^{+}\right)$concentration in the upper 250 m ocean simulated by $(a)$ the coupled GOTM-NODEM model and $(b)$ the uncoupled NODEM, only for 1992.

(a)

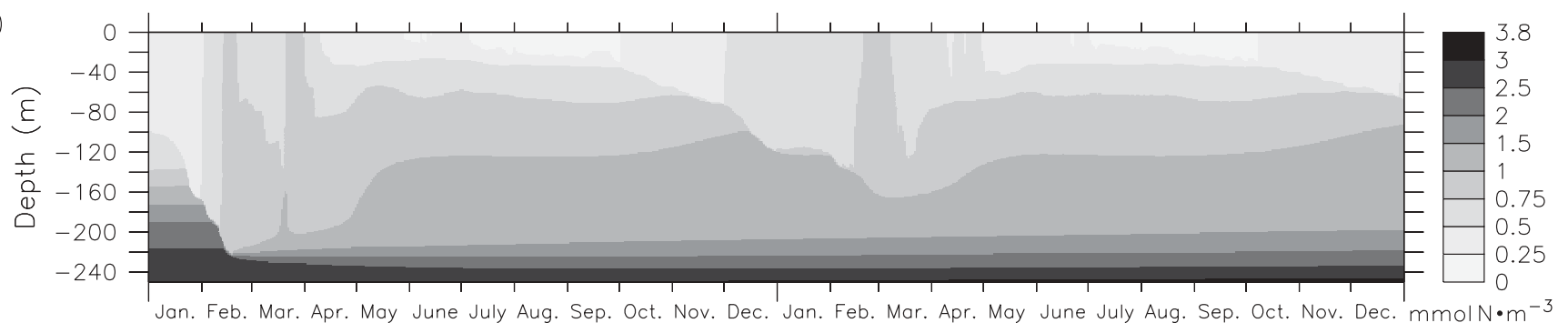

(b)

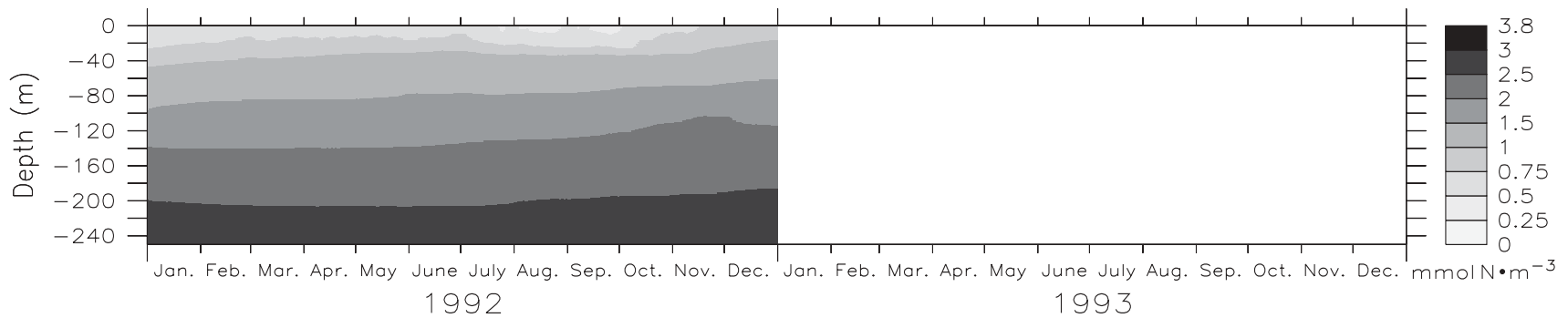

the coupled GOTM-NODEM model simulates a more active system during late winter blooms and a less active system that is nutrient limited in summer. This results from a better reproduction of the seasonal evolution of the nutrient field within the euphotic zone.

\section{Impact on parametric sensitivity of NODEM}

The parametric sensitivity analysis with the uncoupled NODEM model (Lefèvre et al. 2002) showed that DMSP $_{p}$ was dependent mostly on parameters controlling phytoplankton biomass, whereas DMS was dependent mostly on parame- 
Fig. 5. Annual cycle for 1992 and 1993 of Chl $a$ concentration in the upper $250 \mathrm{~m}$ of ocean $(a)$ interpolated from the BATS data set (Michaels and Knap 1996), (b) simulated by the coupled model, and (c) simulated by the uncoupled NODEM and of Chl $a$ in $(d)$ 0to $140-\mathrm{m}$ integrated stocks interpolated from BATS data (red line), simulated by the coupled model (blue line), and simulated by the uncoupled NODEM, only for 1992 (green line).

(a)

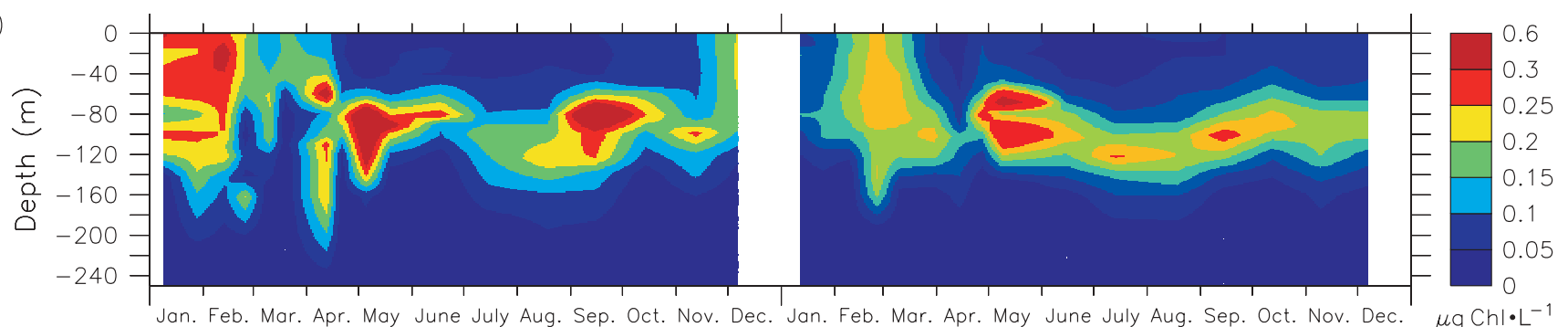

(b)

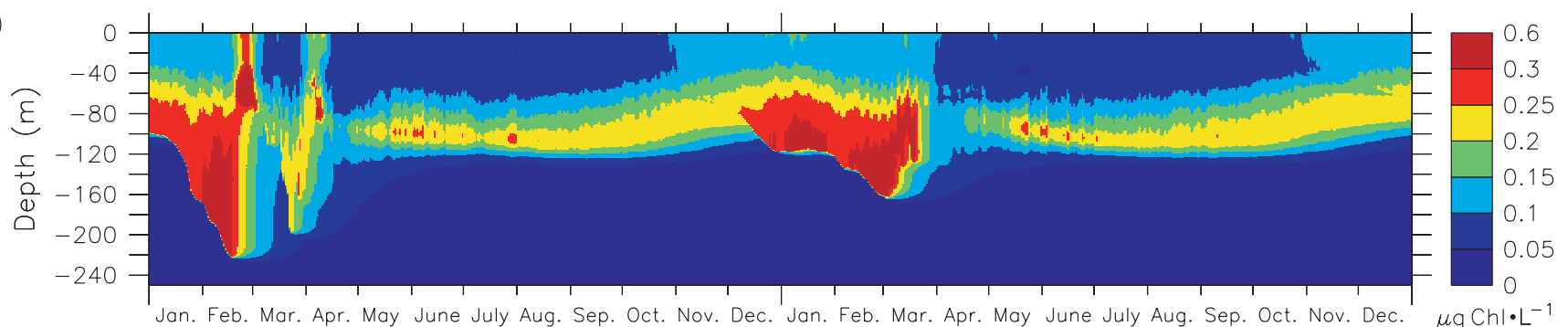

(c)

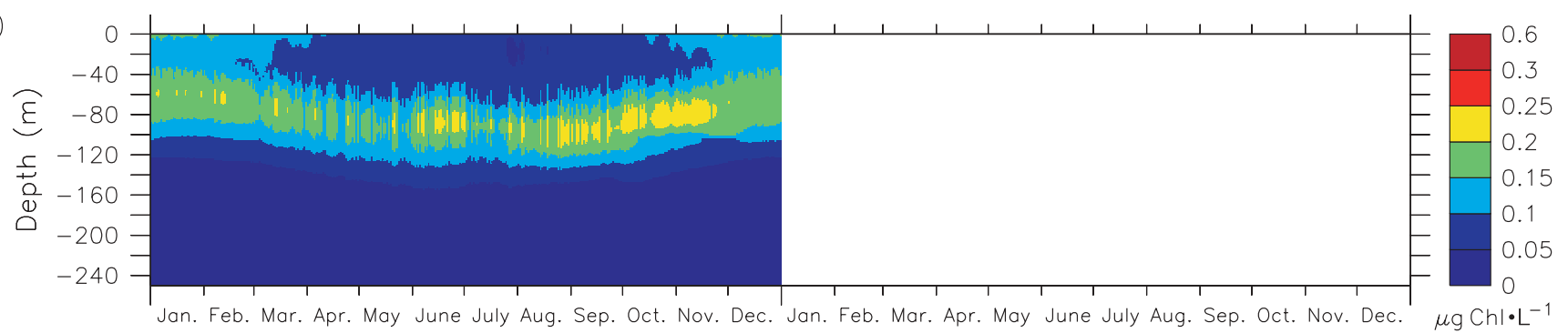

(d)

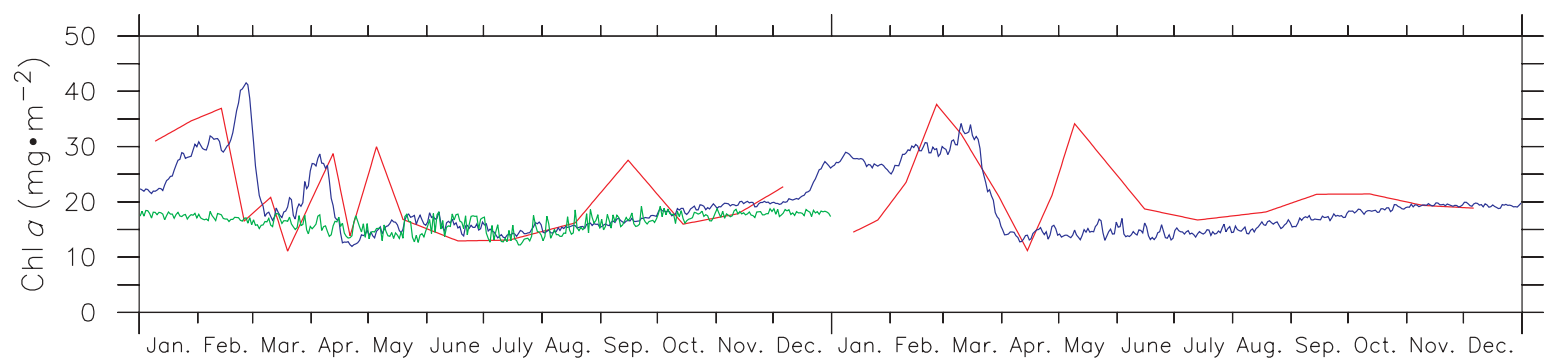

1992

1993

ters controlling phytoplankton productivity. To estimate the impact of the turbulent mixing model on the major biological processes controlling the $\mathrm{DMSP}_{\mathrm{p}}$ and DMS pools, we conduct the same parametric sensitivity analysis as in the previous uncoupled study. For each parameter $k$ used by NODEM (see Appendix A, Table A1), we performed two sensitivity simulations with a variation of this single parameter by plus or minus $50 \%$. All of the sensitivity simulations used the same initialization technique as the reference simulation and started on 1 January 1991. As in Lefèvre et al. (2002), we calculated the index of sensitivity $S_{k}$ of the parameter $k$ on the year 1992 as follows:

$$
S_{k}=\frac{\left(\overline{\operatorname{DMS}(\mathrm{P})_{k_{\max }}}-\overline{\operatorname{DMS}(\mathrm{P})_{k_{\text {min }}}}\right)}{\overline{\operatorname{DMS}(\mathrm{P})_{k}}}
$$

where $\overline{\mathrm{DMS}(\mathrm{P})_{k}}, \overline{\mathrm{DMS}(\mathrm{P})_{k_{\max }}}$, and $\overline{\mathrm{DMS}(\mathrm{P})_{k_{\min }}}$ are the annual

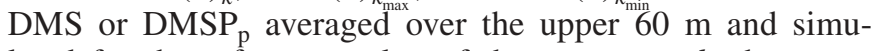
lated for the reference value of the parameter $k$, the upper value $k_{\max }(1.5 \times k)$, and the lower value $k_{\min }(0.5 \times k)$, respectively.

The sensitivity indices of the 1992 annual $\mathrm{DMSP}_{\mathrm{p}}$ and DMS budgets greater than 0.1 are plotted in decreasing order in Figs. $8 a$ and $8 b$, respectively. The results are broadly similar to those obtained with the uncoupled version of NODEM (see fig. 9 in Lefèvre et al. 2002). In particular, the most sensitive parameter remains the variable $S_{\text {DMSP }}: \mathrm{N}$ cell quota. When its minimum and maximum values of variation at the sea surface are changed by $50 \%$, both $\mathrm{DMSP}_{\mathrm{p}}$ and DMS budgets are altered by about $100 \%$. However, some notable differences appear between the coupled and the uncoupled mode. In the coupled GOTM-NODEM model, the DMS budget is less dependent on parameters linked to phyto- 
Fig. 6. Annual cycle for 1992 and 1993 of DMSP $_{\mathrm{p}}$ concentration in the upper $140 \mathrm{~m}$ of ocean (a) interpolated from the observation data set of Dacey et al. (1998), (b) simulated by the coupled model, and (c) simulated by the uncoupled NODEM and of DMSP in $_{\mathrm{p}}$ (d) 0- to 140-m integrated stocks interpolated from observations (red line), simulated by the coupled model (blue line), and simulated by the uncoupled NODEM, only for 1992 (green line).

(a)

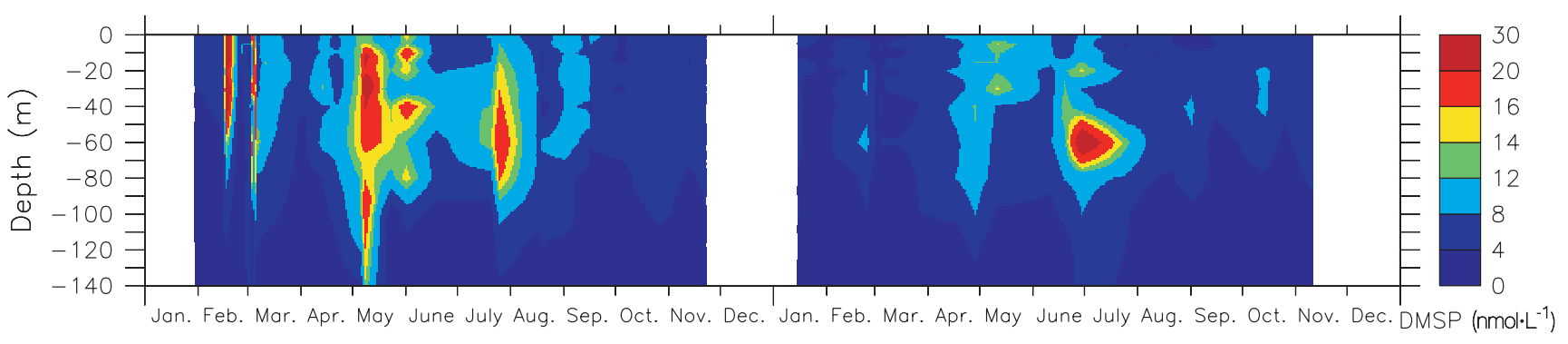

(b)

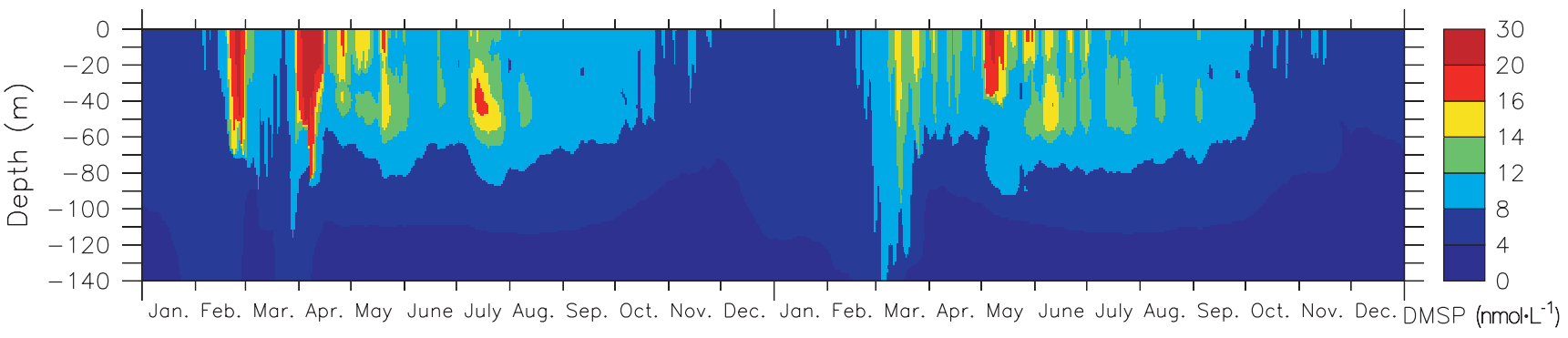

(c)
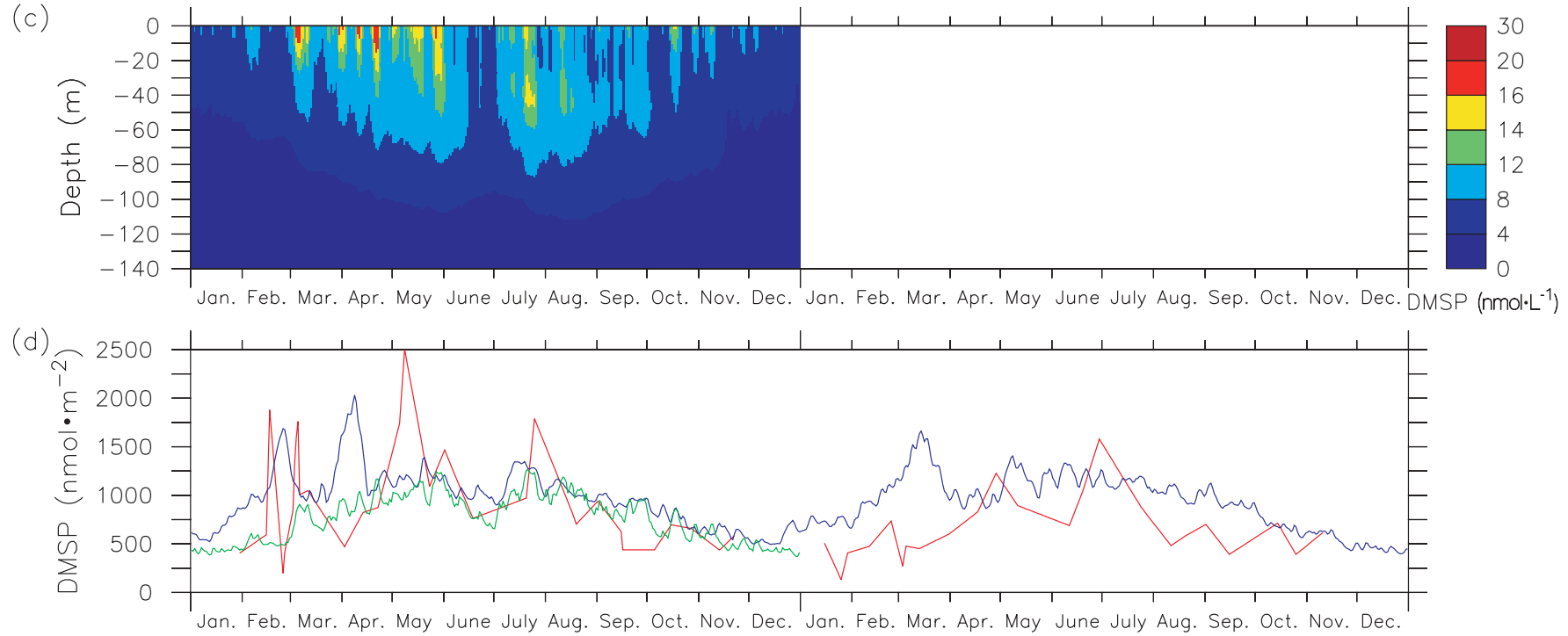

1992

1993

plankton productivity (C:Chl ratio, photosynthetic efficiency, phytoplankton maximum assimilation rate). In contrast with the uncoupled NODEM simulation, the more realistic lower concentration of $\mathrm{NH}_{4}{ }^{+}$simulated by the coupled model (Fig. 4a) limits the possible enhancement of regenerated primary production due to those parameters variations. The increase over 0.1 of the DMS sensitivity to parameters linked to the $\mathrm{NH}_{4}{ }^{+}$pool (remineralization of DON, $\mathrm{NH}_{4}{ }^{+}$uptake) confirms this change. In this more nutrient-limited system simulated by the coupled model, the turnover of phytoplankton biomass is weaker during most of the year, especially in the upper $60 \mathrm{~m}$. The production of DMS via the grazing pathway is reduced compared with the uncoupled NODEM simulation. The sensitivity of DMS to parameters related to microzooplankton (grazing halfsaturation coefficient, maximum grazing rate, excretion rate, natural mortality) is reduced, whereas the sensitivity of DMSP $_{p}$ is enhanced. With regard to the reductions of the sensitivity of DMS to the parameters controlling the nitrogen cycle, the parameters involved in DMS removal (DMS bacterial degradation, photolysis) appear to be more important to the variations in the DMS budget. Overall, the coupling with the prognostic turbulent mixing model makes the DMS pool less sensitive to the nitrogen dynamics of the system.

\section{Limitations of the coupled model}

Driven by the increase in biomass at the beginning of April, which is coherent with the observations (Fig. 5), the coupled model simulates a large peak of $\mathrm{DMSP}_{\mathrm{p}}$ production in the upper ocean that is not present in the observations. However, the local maximum of DMS that develops just af- 
Fig. 7. Annual cycle for 1992 and 1993 of DMS concentration in the upper $140 \mathrm{~m}$ of ocean (a) interpolated from the observation data set of Dacey et al. (1998), (b) simulated by the coupled model, and (c) simulated by the uncoupled NODEM and of DMS in (d) 0- to 140-m integrated stocks interpolated from observations (red line), simulated by the coupled model (blue line), and simulated by the uncoupled NODEM, only for 1992 (green line).

(a)

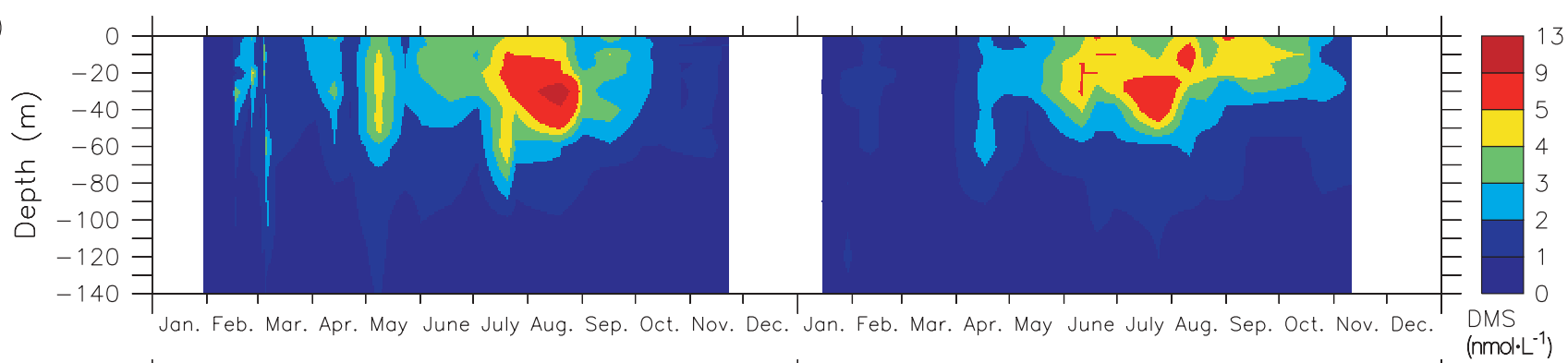

(b)

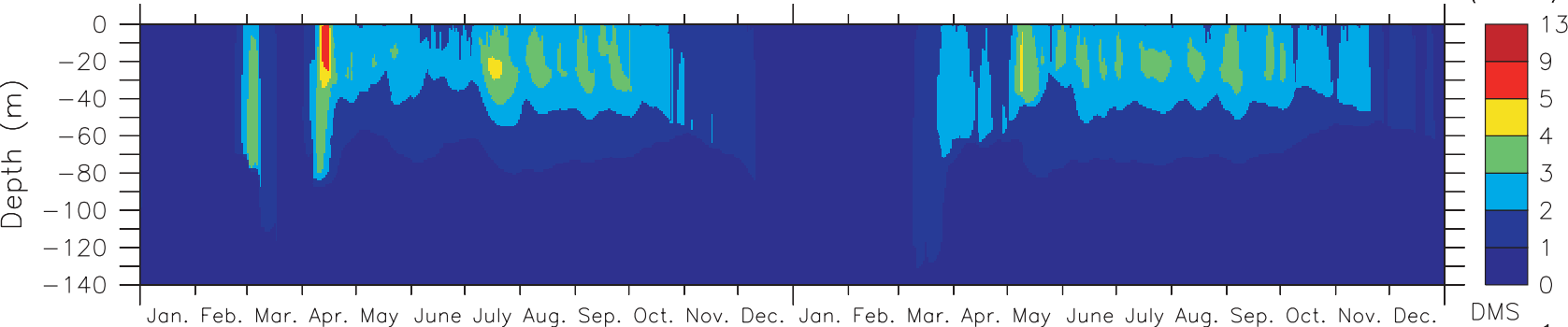

(c)

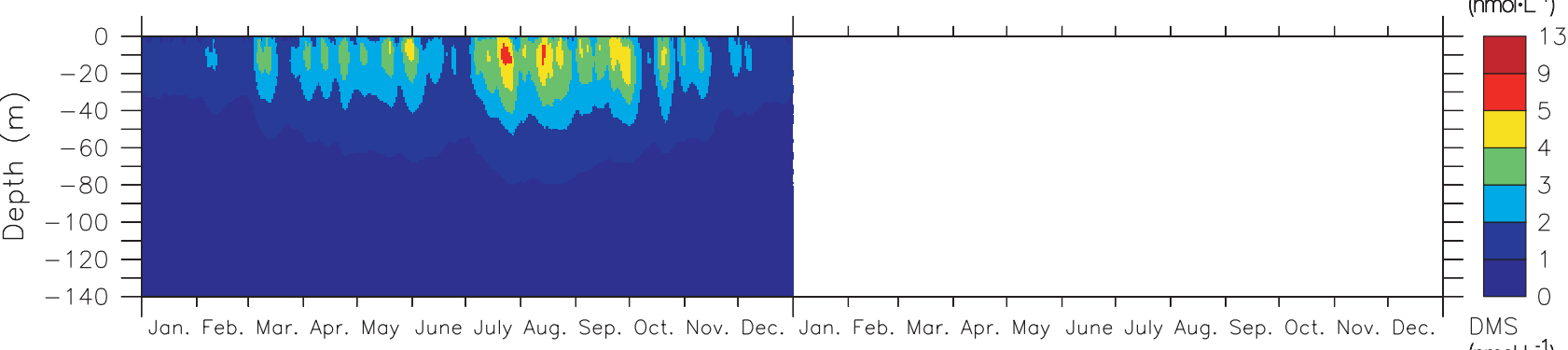

(d)

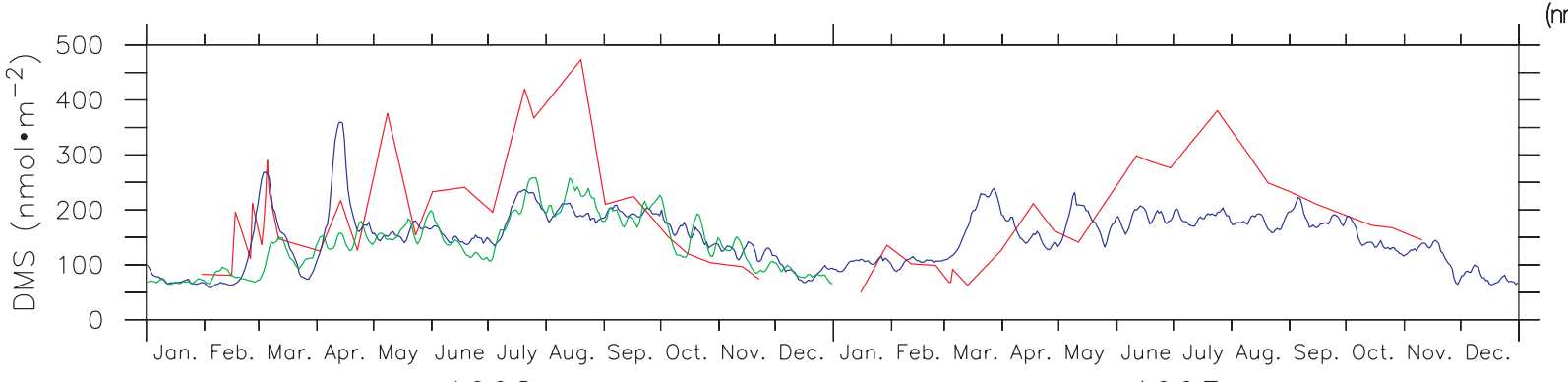

1992

1993

ter is found in the data, but with smaller amplitude. The DMS(P) cycle simulated by the coupled model appears to be too productive during April 1992, especially the production of $\mathrm{DMSP}_{\mathrm{p}}$. The very sensitive parameter $\mathrm{S}: \mathrm{N}$ ratio at the sea surface, which varies according to the surface irradiance at noon, reaches high values during April. Such values do not agree with a phytoplankton community dominated by low DMSP producers, which should dominate during this period (Michaels et al. 1994). This result shows the limitations of our parameterization in reproducing the seasonal effects on community structure.

The coupled model captures the winter blooms but not the subsurface blooms that occur during May and September 1992 and also during May 1993. For these three periods, the temperature contours (Fig. 3c) point to important upward displacements of the $19{ }^{\circ} \mathrm{C}$ isotherm that characterize the passage of mesoscale eddies (McGillicuddy et al. 1998). The upwelling mechanism associated with such eddies involves $\mathrm{NO}_{3}{ }^{-}$injection that stimulates phytoplankton growth (McGillicuddy et al. 1998). The observed subsurface Chl increases may result from this mechanism and thus cannot be reproduced with a one-dimensional model, irrespective of the vertical turbulence representation that is used. A threedimensional eddy-resolving ocean model is needed to capture this mesoscale variability. The peaks of $\mathrm{DMSP}_{\mathrm{p}}$ and DMS observed during May 1992 seem to be also linked to the passage of the eddy. However, the mechanism involved is less clear, since the other subsurface blooms in September 1992 and May 1993 are not accompanied by increases of $\mathrm{DMSP}_{\mathrm{p}}$ and especially of DMS. 
Fig. 8. Sensitivity index of 1992 annual (a) DMSP p $_{\mathrm{p}}$ and (b) DMS budgets averaged over the upper $60 \mathrm{~m}$ when parameters used in the coupled model are varied by $\pm 50 \%$. Black bars indicate positive sensitivity indices (increase of budget when the parameter is increased by 50\%) and shaded ones indicate negative indices. Zoo., zooplankton; Phyto., phytoplankton; half-sat., half-saturation coefficient.

(a)

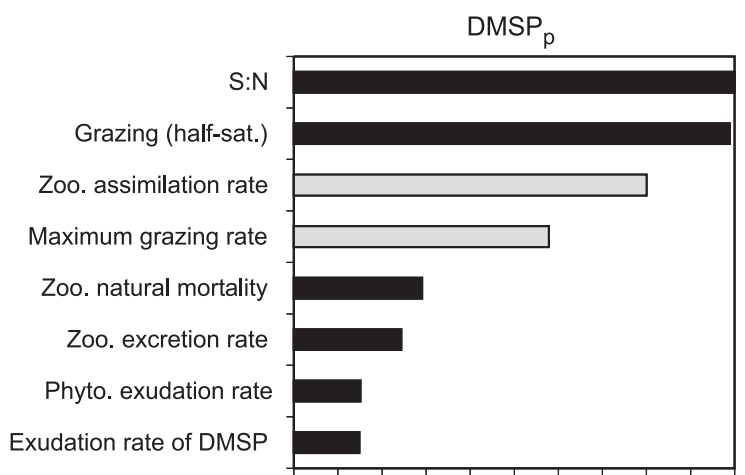

$\begin{array}{llllllllllll}0.0 & 0.1 & 0.2 & 0.3 & 0.4 & 0.5 & 0.6 & 0.7 & 0.8 & 0.9 & 1.0\end{array}$ Sensitivity index

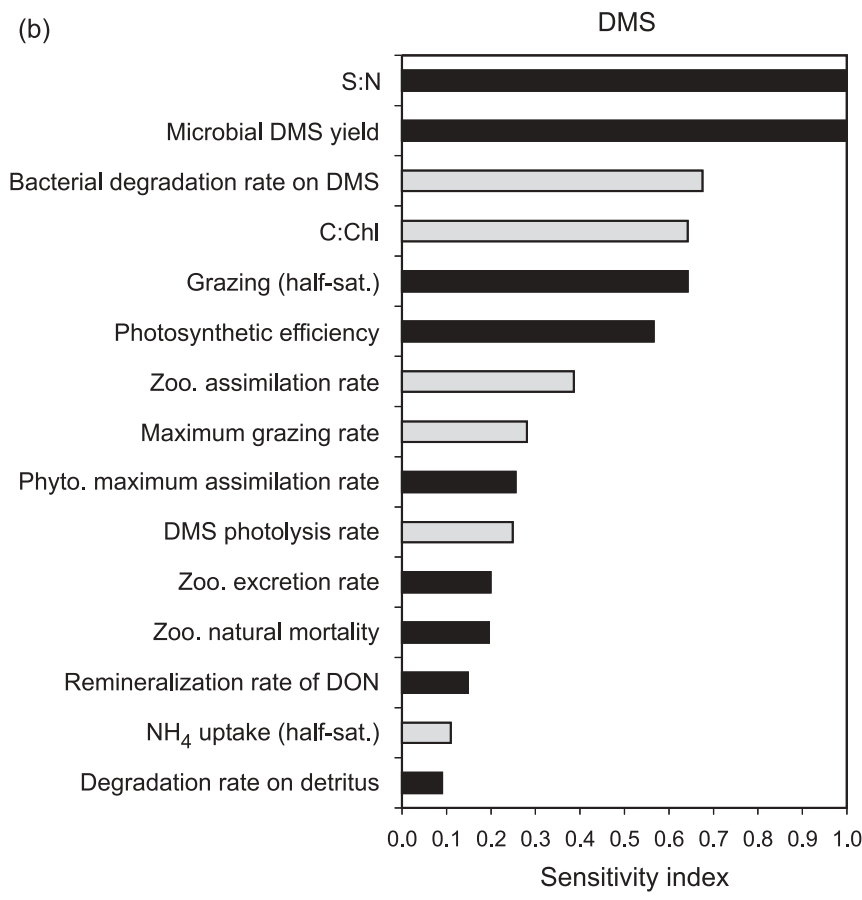

\section{Limitations of parameterizations of DMS dynamics}

Despite a more realistic simulation of the summer ecosystem dynamics, the coupled model tends to overestimate DMSP $_{\mathrm{p}}$ concentrations in the top $40 \mathrm{~m}$ (Fig. 6b) and to underestimate the DMS summer peak (Fig. 7b). Considering the large $\mathrm{DMSP}_{\mathrm{p}}$ pool simulated in summer, the underestimation of DMS concentration does not result from a lack of $\mathrm{DMSP}_{\mathrm{p}}$ synthesis. The simulated $\mathrm{DMSP}_{\mathrm{d}}$ pool (not shown), which presents a structure similar to that of DMS, is also not underestimated compared with the data. The weakness of the summer DMS peak may result from incorrect modeling of the DMS budget.
Our sensitivity analysis has confirmed the high sensitivity of DMS concentration to DMS yield (which determined the gross production of DMS from the $\mathrm{DMSP}_{\mathrm{d}}$ pool) and to parameters controlling DMS removal (DMS bacterial degradation, photolysis). The DMS yield was fixed at $40 \%$ in our model, leading to a high correlation between DMS and DMSP $_{d}$ variations (not shown) that is not observed in situ (Dacey et al. 1998). Different field studies (Ledyard and Dacey 1996; Simó and Pedrós-Alió 1999; Scarratt et al. 2000) have shown both spatial and temporal variations of the DMS yield. Based on different data in the Northern Hemisphere, Simó and Pedrós-Alió (1999) proposed that DMS yield varies with mixed layer depth. Their asymmetric relationship presents a minimum yield at a mixed layer depth of 15-20 m. These are the depths found from April to September at BATS. The introduction of a variable DMS yield in the model may well be desirable. However, the only published study does not offer a solution to the model underestimate of summer DMS concentrations.

Photolysis is an important sink for DMS in the upper ocean. In the model, its parameterization is based on visible radiation following Kieber et al. (1996). However, recent field studies (Toole et al. 2003) indicate the predominance of UV radiation on the photochemistry of DMS. This suggests an overestimation of the photolysis in summer by our model (R-C. Bouillon, Department of Oceanography, Dalhousie University, Halifax, NS B3H 4J1, Canada, personal communication). The UV radiation is not yet computed in our spectral module. A specific modeling study is needed to test the influence of a photolysis parameterization based on UV radiation.

The bacterial degradation rate on DMS is also one of the most sensitive parameter for DMS (Fig. 8b). It is fixed to $0.4 \cdot \mathrm{day}^{-1}$ in NODEM. This value is in the range of the values estimated by Kiene (1992) and Kiene and Linn (2000) in the Sargasso Sea, but it may display a seasonal variability (Ledyard and Dacey 1996). In contrast with the zerodimensional DMS model developed by Gabric et al. (1993), bacteria are not explicitly modeled in NODEM. Because they play an important role in the production and consumption of volatile sulfur and are under the influence of physical forcing (temperature, UV radiation, mixing), they may contribute to the variability of the system (Simò 2001). However, the understanding and quantification of their exact role need to be studied thoroughly in both field and numerical modeling studies.

\section{Validation with independent data (1993)}

The coupled model predictions for the independent 1993 data using the same ecosystem parameters as for the calibration year 1992 are similar to the 1992 results and reproduce the main structure of the 1993 annual cycle. However, we should note that the variations of the $S: N$ ratio and the depth dependence of the $\mathrm{C}: \mathrm{Chl}$ ratio are changed because they are linked to the surface irradiance, which differs between years. The coupled model succeeds in capturing part of the interannual variability between 1992 and 1993. Both simulations and observations (Michaels and Knap 1996) point to only one deep winter mixing event occurring in 1993 leading to a single winter phytoplankton bloom (Fig. 4d). This contrasts with the multiple blooms observed and simulated for 1992. 
Moreover, the lower depth of winter mixing in 1993 is also well captured. On the other hand, the model does not reproduce the higher intensity of the subsurface Chl maximum in summer 1993 than in summer 1992.

The same limitations are found in this second year of simulation as in the first one. The simulated winter bloom shows a time lag compared with the observations, and the vertical profile of Chl $a$ shows an important gradient with subsurface values higher than near the surface. The subsurface increase of Chl $a$ in May 1993 that is possibly linked to the passage of an eddy (see Fig. 3) is not reproduced. The DMSP and DMS concentrations reach a peak in May 1993, when the S:N surface ratio calculated reaches its highest values. An increase of DMSP $_{p}$ is observed in May 1993 but is not as marked as in the model simulation.

The simulated 0- to $140-\mathrm{m}$ integrated stocks of $\mathrm{DMSP}_{\mathrm{p}}$ and DMS are comparable between 1992 and 1993, whereas the observations show significant differences. The observed DMSP $_{\mathrm{p}}$ pool is smaller in 1993; consequently, the model overestimation is stronger for 1993 than for 1992. However, in accord with the observations of Dacey et al. (1998), the intensity of the $\mathrm{DMSP}_{\mathrm{p}}$ and DMS peaks simulated in winter and spring 1993 is reduced in comparison with 1992. In summer, the observed DMS peak is broader (stretched over a longer period) and lower in 1993 than in 1992. The model differs little in its simulation of summer dynamics between these two years. However, because the model simulates a broader and lower DMS peak than observed, it is closer to the 1993 summer DMS data than to the 1992 summer data.

These comparisons indicate that using prognostic mixed layer physics is not sufficient to reproduce all of the interannual variability in the DMS pool dynamics. Improvements of the ecosystem model itself are required. The present parameterization used to mimic seasonal changes in phytoplankton composition is obviously a simplification that limits our model. The problems described above occurred equally in both years of the simulation (i.e., variations of the $\mathrm{C}$ :Chl ratio with depth, high variability of the $\mathrm{S}: \mathrm{N}$ ratio, underestimation of summer DMS peak). Moreover, the model does not simulate the lower $\mathrm{DMSP}_{\mathrm{p}}$ concentrations measured in 1993 even though it reproduces the Chl levels correctly for both years. The $\mathrm{S}: \mathrm{N}$ ratio is the most sensitive parameter of the model, but processes controlling the $\mathrm{S}_{\mathrm{DMSP}}: \mathrm{N}$ quota are not yet well known (Simò 2001). The parameterization of this ratio should be a priority for future field and modeling work to replace the semiempirical approach. Incidentally, the complex variations of the phytoplankton community structure need also to be addressed by a more sophisticated implicit parameterization (Denman 2003) or ultimately by a functional group approach. The representation of the role of bacteria needs also to be investigated in detail.

In summary, we have constructed a new one-dimensional coupled physical-biogeochemical ocean model by coupling the DMS production model NODEM with the water column ocean model GOTM that includes a two-equation $k-\varepsilon$ turbulence closure scheme (Burchard et al. 1999). This model proved to be a significant improvement over a previous version of NODEM that was driven by a diagnostic vertical mixing scheme (Lefèvre et al. 2002). Using the same set of biogeochemical parameters as the uncoupled NODEM version, the coupled model GOTM-NODEM was able to im- prove the simulations of the 1992 time series of DMS(P) collected at Hydrostation S by Dacey et al. (1998). Simply by better reproduction of the mixing environment, the coupled model was able to capture winter phytoplankton blooms largely missed by the uncoupled model. Moreover, the coupled model proved to be more adept at reproducing summer stratification at Hydrostation $\mathrm{S}$ and consequently the prediction of the summer vertical structure in phytoplankton biomass and DMS concentration. This points to the importance of high-resolution prognostic physical modeling in reproducing not only the variability in biological-chemical systems that affect DMS(P) concentrations but also their dynamics during stable periods when nutrient recycling dominates. The use of prognostic mixing also changed our view of the model parameters that are most critical to predictions of DMS(P) levels. Compared with the previous version of NODEM, and compared also with most previously published models that use bulk mixing parameterizations (Vezina 2004), parameters related to the sulfur cycle become more important in relation to parameters controlling the nitrogen cycle. A better representation of mixing corrects deficiencies in nitrogen cycling and shifts the sensitivities towards the sulfur parameters. Finally, the coupled model was able to reproduce some of the observed differences in DMS dynamics between 1992 and 1993, the latter being an independent data set not used in developing NODEM. Based on this work, significant improvements in DMS modeling will arise first from developing better parameterizations of the time and space dependence of processes that affect DMS removal, as well as those affecting DMS production (e.g., phytoplankton growth and variability in cell sulfur quota). Secondly, extensions to eddy-resolving three-dimensional modeling should bring some improvements to ocean areas like BATS that are known to be influenced by a strong eddy field.

\section{Acknowledgements}

This work was supported in part by the Government of Canada's Climate Change Action Fund and by the Canadian-SOLAS Network (Surface Ocean - Lower Atmosphere Study) of the Natural Sciences and Engineering Research Council of Canada and the Canadian Foundation for Climate and Atmospheric Sciences. The authors wish to thank the entire GOTM project team for the code of GOTM and in particular H. Burchard, K. Bolding, and P.P. Mathieu for their help. We also thank the team of the Bermuda Research Station for the Hydrostation $S$ data set (available from www.bbsr.edu) and the team of the NCEP/NCAR 40year reanalysis project for atmospheric data. Most of the graphics in this paper were created with the Ferret program. Ferret is a product of NOAA's Pacific Marine Environmental Laboratory (www.ferret.noaa.gov). We are grateful to the two anonymous reviewers for their constructive comments on the first version of this manuscript.

\section{References}

Andreae, M.O., and Crutzen, P.J. 1997. Atmospheric aerosols: biogeochemical sources and role in the atmospheric chemistry. Science (Wash., D.C.), 276: 1052-1058. 
Bates, T.S., Lamb, B.K., Guenther, A., Dignon, J., and Stoiber, R.E. 1992. Sulfur emissions to the atmosphere from natural sources. J. Atmos. Chem. 14: 315-337.

Bissett, W.P., Meyers, M.B., Walsh, J.G., and Muller-Karger, F.E. 1994. The effects of temporal variability of mixed layer depth on primary productivity around Bermuda. J. Geophys. Res. 99(C4): 7539-7553.

Bopp, L., Aumont, O., Belviso, S., and Monfray, P. 2003. Potential impact of climate change on marine dimethylsulfide emissions. Tellus Ser. B Chem. Phys. Meteorol. 55: 11-22.

Burchard, H., and Baumert, H. 1995. On the performance of a mixedlayer model based on the $k-\varepsilon$ turbulence closure. J. Geophys. Res. 100(C5): 8523-8540.

Burchard, H., and Petersen, O. 1999. Models of turbulence in the marine environment - a comparative study of two-equation turbulence models. J. Mar. Syst. 21: 29-53.

Burchard, H., Bolding, K., and Villarreal, M.R. 1999. GOTM - a general ocean turbulence model. Theory, applications and test cases. Tech. Rep. EUR 18745, European Commission.

Charlson, R.J., Lovelock, J.E., Andreae, M.O., and Warren, S.G. 1987. Oceanic phytoplankon, atmospheric sulfur, cloud albedo and climate. Nature (Lond.), 326: 655-661.

Chin, M., and Jacob, D.J. 1996. Anthropogenic and natural contributions to tropospheric sulfate: a global model analysis. J. Gephys. Res. 101(D13): 18691 - 18699.

Clarke, A.D., Varmer, J.L., Eisele, F., Maudlin, R.L., Tanner, D., and Litchy, M. 1998. Particle nucleation in the tropical boundary layer and its coupling to marine sulfur sources. Science (Wash., D.C.), 282: 89-92.

Dacey, J.W.H., Howse, F.A., Michaels, A.F., and Wakeham, S.G. 1998. Temporal variability of dimethylsulfide and dimethylsulfoniopropionate in the Sargasso Sea. Deep-Sea Res. I, 45: 2085-2104.

Denman, K.L. 2003. Modelling planktonic ecosystems: parameterizing complexity. Prog. Oceanogr. 57(3-4): 429-452.

Denman, K.L., and Gargett, A.E. 1983. Time and space scales of vertical mixing and advection of phytoplankton in the upper ocean. Limnol. Oceanogr. 28: 801-815.

Doney, S.C., Glover, D.M., and Najjar, R.G. 1996. A new coupled, one-dimensionnal biological-physical model for the upper ocean: applications to the JGOFS Bermuda Atlantic time-series study (BATS) site. Deep-Sea Res. II, 43(2-3): 591-624.

Falkowski, P.G., Kim, Y., Kolber, Z., Wilson, C., Wirik, C., and Cess, R. 1992. Natural versus anthropogenic factors affecting low-level cloud albedo over the North Atlantic. Science (Wash., D.C.), 256: 1311-1313.

Fasham, M.J.R., Ducklow, H.W., and McKelvie, S.M. 1990. A nitrogen-based model of plankton dynamics in the oceanic mixed layer. J. Mar. Res. 48: 591-639.

Foley, J.A., Taylor, K.E., and Ghan, S.J. 1991. Planktonic dimethylsulfide and cloud albedo: an estimate of the feedback response. Clim. Change, 18: 1-15.

Gabric, A., Murray, N., Stone, L., and Kohl, M. 1993. Modeling the production of dimethylsulfide during a phytoplankton bloom. J. Geophys. Res. 98(C12): 22805 - 22816.

Gabric, A.J., Whetton, P.H., Boers, R., and Ayers, G.P. 1998. The impact of simulated climate change on the air-sea flux of dimethylsulphide in the subantarctic Southern Ocean. Tellus Ser. B Chem. Phys. Meteorol. 50: 388-399.

Gabric, A.J., Whetton, P.H., and Cropp, R. 2001. Dimethylsulphide production in the subantarctic southern ocean under enhanced greenhouse gas conditions. Tellus Ser. B Chem. Phys. Meteorol. 53: $273-287$.
Houghton, J.T., Ding, Y., Griggs, D.J., Noguer, M., Van der Linden, P.J., and Xiaosu, D. (Editors). 2001. Climate change 2001: the scientific basis. Contribution of Working Group I to the Third Assessment Report of the Intergovernmental Panel on Climate Change (IPCC). Cambridge University Press, Cambridge,U.K.

Hurtt, G.C., and Armstrong, R.A. 1996. A pelagic ecosystem model calibrated with BATS data. Deep-Sea Res. II, 43(2-3): 653-683.

Jodwalis, C.M., Benner, R.L., and Eslinger, D.L. 2000. Modeling of dimethyl sulfide ocean mixing, biological production, and sea-to-air flux for high latitudes. J. Geophys. Res. 105(D11): 14387 - 14399.

Kalnay, E., Kanamitsu, M., Kistler, R., Collins, W., Deaven, D., Gandin, L., Iredell, M., Saha, S., White, G., Woollen, J., et al. 1996. The NCEP/NCAR 40-year reanalysis project. B. Am. Meteorol. Soc. 77: 437-472.

Kantha, L.H., and Clayson, C.A. 1994. An improved mixed layer model for geophysical applications. J. Geophys. Res. 99(C12): 25235 - 25266.

Keller, M.D. 1989. Dimethyl sulfide production and marine phytoplankton: the importance of species composition and cell size. Biol. Oceanogr. 6(5-6): 375-382.

Keller, M.D., Kiene, R.P., Matrai, P.A., and Bellows, W.K. 1999. Production of glycine betaine and dimethylsulfoniopropionate in marine phytoplankton. II. N-limited chemostat cultures. Mar. Biol. 135: 249-257.

Kettle, A.J., and Andreae, M.O. 2000. Flux of dimethylsulfide from the oceans: a comparison of updated data sets and flux models. J. Geophys. Res. 105(D22): 26793 - 26808.

Kieber, D.J., Jiao, J., Kiene, R.P., and Bates, T.S. 1996. Impact of dimethylsulfide photochemistry on methyl sulfur cycling in the Equatorial Pacific Ocean. J. Geophys. Res. 101(C2): 3715-3722.

Kiene, R.P. 1992. Dynamics of dimethylsulfide and dimethylsulfoniopropionate in oceanic water samples. Mar. Chem. 37(1-2): 29-52.

Kiene, R.P., and Linn, L.J. 2000. The fate of dissolved dimethylsulfoniopropionate (DMSP) in seawater: tracer studies using ${ }^{35}$ S-DMSP. Geochim. Cosmochim. Acta, 64: 2797-2810.

Knap, A.H., Michaels, A.F., Dow, R.L., Johnson, R.J., Gundersen, K., Sorensen, J.C., et al. 1993. Bermuda Atlantic time-series study. BATS Data Rep. B-3. Joint Global Ocean Flux Study. pp. 25-36.

Knap, A.H., Michaels, A.F., Dow, R.L., Johnson, R.J., Gundersen, K., Sorensen, J.C., et al. 1994. Bermuda Atlantic time-series study. BATS Data Rep. B-4. Joint Global Ocean Flux Study. pp. 37-48.

Knap, A.H., Michaels, A.F., Dow, R.L., Johnson, R.J., Gundersen, K., Sorensen, J.C., et al. 1995. Bermuda Atlantic time-series study. BATS Data Rep. B-5. Joint Global Ocean Flux Study. pp. 49-60.

Knap, A.H., Michaels, A.F., Hansell, D., Bahr, F., Bates, N., Becker, S., et al. 1997. Bermuda Atlantic time-series study. BATS Data Rep. B-6. Joint Global Ocean Flux Study. pp. 61-72.

Large, W.G., McWilliams, J.C., and Doney, S.C. 1994. Oceanic vertical mixing: a review and a model with nonlocal boundary layer parameterization. Rev. Geophys. 32: 363-403.

Lawrence, M.G. 1993. An empirical analysis of the strength of the phytoplankton-dimethylsulfide-cloud-climate feedback cycle. J. Geophys. Res. 98(D11): 20 633-20 673.

Ledyard, K.M., and Dacey, J.W.H. 1996. Microbial cycling of DMSP and DMS in coastal and oligotrophic seawater. Limnol. Oceanogr. 41: $33-40$.

Lefèvre, M., Vézina, A., Levasseur, M., and Dacey, J.W.H. 2002. A model of dimethylsulfide dynamics for the subtropical North Atlantic. Deep-Sea Res. I, 49: 2221-2239.

Lipschultz, F. 2001. A time-series assessment of the nitrogen cycle at BATS. Deep-Sea Res. II, 48(8-9): 1897-1924. 
Malin, G., and Kirst, G.O. 1997. Algal production of dimethylsulfide and its atmospheric role. J. Phycol. 33: 889-896.

Malone, T.C., Pike, S.E., and Conley, D.J. 1993. Transient variations in phytoplankton productivity at the JGOFS Bermuda time series station. Deep-Sea Res. I, 40: 903-924.

Mann, K.H., and Lazier, R.N. 1991. Dynamics of marine ecosystems, biological-physical interactions in the oceans. Blackwell Scientific Publications, Boston, Mass.

McGillicuddy, J.D.J., Robinson, A.R., Siegel, D.A., Jannasch, H.W., Johnson, R., Dickey, T.D., McNeil, J., Michaels, A.F., and Knap, A.H. 1998. Influence of mesoscale eddies on the new production in the Sargasso Sea. Nature (Lond.), 394: 263-266.

Michaels, A.F., and Knap, A.H. 1996. Overview of the U.S. JGOFS Bermuda Atlantic time-series study and the Hydrostation S program. Deep-Sea Res. II, 43(2-3): 157-198.

Michaels, A.F., Knap, A.H., Dow, R.L., Gundersen, K., Johnson, R.J., Sorensen, J.C., Close, A., Knauer, G.A., Lohrentz, S.E., Asper, V.A., et al. 1994. Seasonal patterns of ocean biogeochemistry at the U.S. JGOFS Bermuda Atlantic time-series study site. Deep-Sea Res. I, 41: 1013-1038.

Mitchell, J.F.B., Johns, T.C., Gregory, J.M., and Tett, S.F.B. 1995. Climate response to increasing levels of greenhouse gases and sulfate aerosols. Nature (Lond.), 376: 501-504.

Rodhe, H. 1999. Human impact on the atmospheric sulfur balance. Tellus Ser. A-B, 51: 110-122.

Sathyendranath, S., and Platt, T. 1988. The spectral irradiance field at the surface and in the interior of the ocean: a model for application in oceanography and remote sensing. J. Gephys. Res. 98(C8): 9270-9280.

Sathyendranath, S., and Platt, T. 1989. Computation of aquatic primary production: extended formalism to include effect of angular and spectral distribution of light. Limnol. Oceanogr. 34: 188-198.

Sathyendranath, S., Platt, T., Caverhill, C.M., Warnock, R.E., and Lewis, M.R. 1989. Remote sensing of oceanic primary production: computations using a spectral model. Deep-Sea Res. I, 36: 431-453.

Scarratt, M., Cantin, G., Levasseur, M., and Michaud, S. 2000. Particle size-fractionated kinetics of DMS production: where does DMSP cleavage occur at the microscale? J. Sea Res. 43(3-4): 245-252.

Scarratt, M., Levasseur, M., Michaud, S., Cantin, G., Gosselin, M., and de Mora, M.J. 2002. Influence of phytoplankton taxonomic profile on the distribution of dimethylsulfide and dimethylsulfoniopropionate in the northwest Atlantic. Mar. Ecol. Prog. Ser. 244: 49-61.

Simó, R. 2001. Production of atmospheric sulfur by oceanic plankton: biogeochemical, ecological and evolutionary links. Trends Ecol. Evol. 16: 287-294.

Simó, R., and Pedrós-Alió, C. 1999. Role of vertical mixing in controlling the oceanic production of dimethyl sulphide. Nature (Lond.), 402: 396-397.

Simó, R., Archer, S.D., Pedrós-Alió, C., Gilpin, L., and StelfoxWiddicombe, C.E. 2002. Coupled dynamics of dimethylsulfoniopropriate and dimethylsulfide cycling and the microbial food web in surface waters of the North Atlantic. Limnol. Oceanogr. 47: 53-61.

Toole, D.A., Kieber, D.J., Kiene, R.P., Siegel, D.A., and Nelson, N.B. 2003. Photolysis and the dimethylsulfide (DMS) summer paradox in the Sargasso Sea. Limnol. Oceanogr. 48: 1088-1100.

Vézina, A.F. 2004. Towards modelling marine DMS production and emissions over regional and global scales. Can. J. Fish. Aquat. Sci. 61(5). This issue.

Wanninkhof, R. 1992. Relationship between wind speed and gas exchange over the ocean. J. Geophys. Res. 97(C5): 7373-7382.

\section{Appendix A}

This appendix presents the complete equations for the nitrogen cycling and sulfur cycling state variables used in the model. The left-hand side of the equations follows the general form of the transport equation (eq. 1), where the term $v_{\mathrm{t}} \frac{\partial X}{\partial z}$ represents the turbulent flux of the quantity $X$. The right-hand side points out the production and consumption terms that are calculated by the accurate module. The functions for phytoplankton growth, photosynthesis, and grazing are also depicted. A description of these parameters, including units and values used in the model, is presented in Table A1. We kept the same parameter values as in the uncoupled NODEM simulation, which are fully discussed in Lefèvre et al. (2002).

\section{Equation for nitrogen cycling (ecosystem module)}

Phytoplankton:

$$
\begin{aligned}
\frac{\partial P}{\partial t}-\frac{\partial}{\partial z}\left(s_{1} P+v_{\mathrm{t}} \frac{\partial P}{\partial z}\right)=\left(P \mu_{\left({\left.\mathrm{PAR}, \mathrm{NH}_{4}, \mathrm{NO}_{3}, T\right)}\right)}\right. & -\left(P\left(e_{1}+m_{1}\right)+Z g_{(P, T)}\right)
\end{aligned}
$$

Phytoplankton growth $(\mu)$ is controlled by light $\left(P^{\mathrm{B}}\right.$ is the light-dependent production), temperature $(T)$, and nitrogen availability as follows:

$$
\begin{aligned}
& \mu= \\
& P^{\mathrm{B}} q_{1}\left(\frac{\left[\mathrm{NO}_{3}\right]^{2}}{\mathrm{Ks}_{\mathrm{NH}_{4}}^{2}+\left[\mathrm{NO}_{3}\right]^{2}}+\frac{\left[\mathrm{NH}_{4}\right]^{2}}{\mathrm{Ks}_{\mathrm{NH}_{4}}^{2}+\left[\mathrm{NH}_{4}\right]^{2}}\right) \mathrm{e}^{-0.069\left(T_{0}-T\right)}
\end{aligned}
$$

Photosynthesis $P^{\mathrm{B}}$ is a function (Sathyendranath et al. 1989; Sathyendranath and Platt 1989) of photosynthetically active radiation at the sea surface irradiance $\left(I_{0}\right)$, underwater attenuation light coefficient $\left(k_{z}\right)$ due to water and algae particles, maximum rate of photosynthesis $\left(P_{\mathrm{m}}^{\mathrm{B}}\right)$ at saturated irradiance normalized to algal biomass, and photosynthetic efficiency at low irradiance $\left(\alpha^{\mathrm{B}}\right)$. The surface irradiance $\left(I_{0}\right)$ and the underwater light field $\left(I_{0_{\lambda \text { doy }}}\right)$ in the euphotic zone are calculated by a spectral model from 400 to $700 \mathrm{~nm}$ (Sathyendranath and Platt 1988). Thus, $P^{\mathrm{B}}$ depends on depth $(z)$, wavelength $(\lambda)$, the day of the year (doy), the day length $(\mathrm{dl})$, and the time of the day $(t)$ :

$$
P^{\mathrm{B}}=P_{\mathrm{m}}^{\mathrm{B}}\left(1-\mathrm{e}^{-\left(\alpha_{\lambda}^{\mathrm{B}} I_{0 \lambda, \mathrm{doy}} \sin (\pi t / \mathrm{dl}) \mathrm{e}^{-k_{z}}\right) / P_{\mathrm{m}}^{\mathrm{B}}}\right)
$$

Microzooplankton:

$$
\frac{\partial Z}{\partial t}-\frac{\partial}{\partial z}\left(v_{\mathrm{t}} \frac{\partial Z}{\partial z}\right)=\left(Z g_{(P, T)} a\right)-\left(Z\left(e_{2}+m_{2}\right)\right)
$$

Grazing $(g)$ is controlled by temperature $(T)$ and phytoplankton $(P)$ availability as follows:

$$
g=V_{\mathrm{m}} \frac{[P]^{2}}{\mathrm{Ks}^{2}+[P]^{2}} \mathrm{e}^{-0.069\left(T_{0}-T\right)}
$$


Table A1. Parameters of the nitrogen and sulfur cycling used in NODEM.

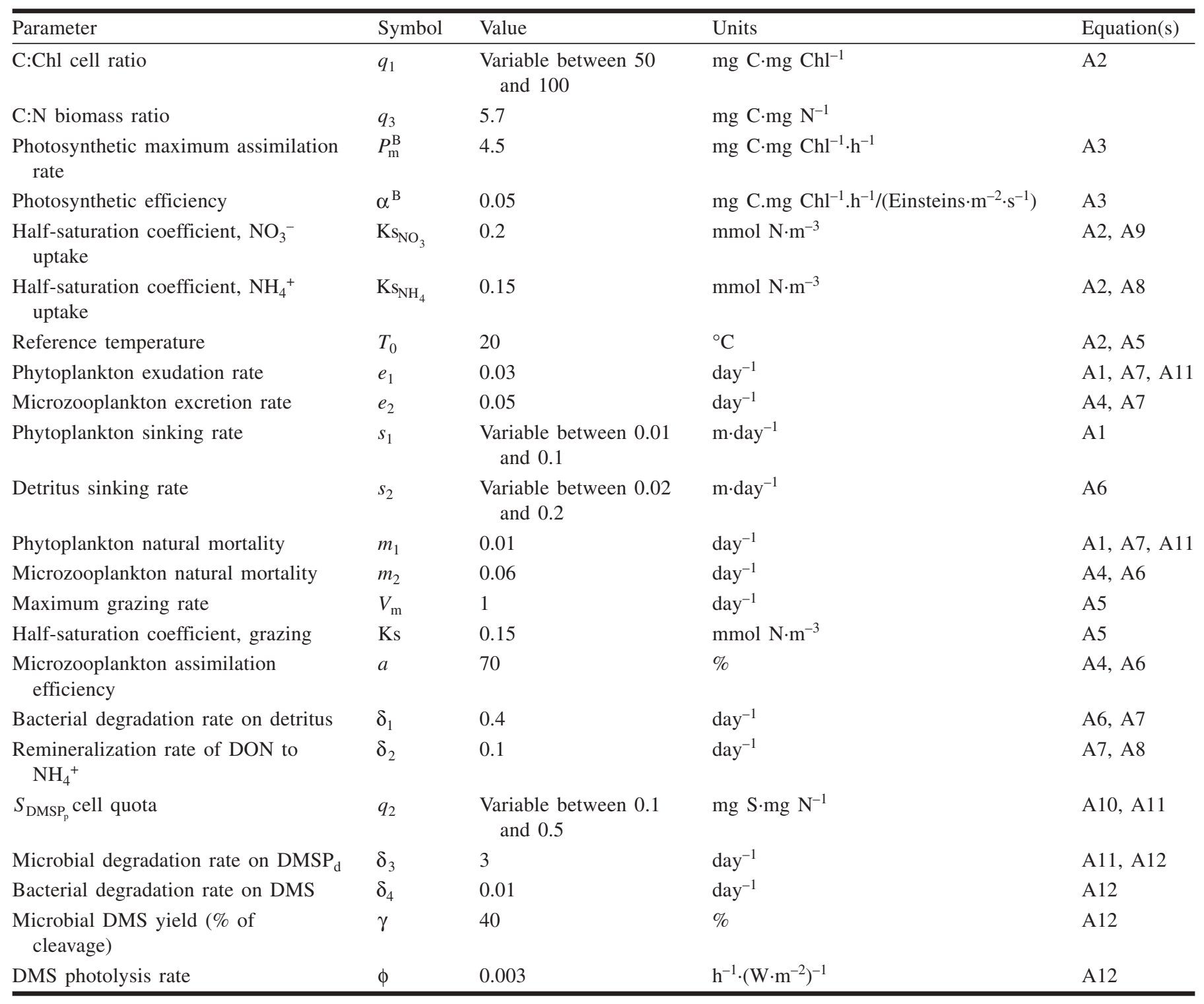

Detritus:

(A6) $\frac{\partial D}{\partial t}-\frac{\partial}{\partial z}\left(s_{2} D+v_{t} \frac{\partial D}{\partial z}\right)=$

$$
\left(Z\left(g_{(P, T)}(1-a)+m_{2}\right)\right)-D \delta_{1}
$$

DON:

$$
\begin{aligned}
& \frac{\partial \mathrm{DON}}{\partial t}-\frac{\partial}{\partial z}\left(v_{\mathrm{t}} \frac{\partial \mathrm{DON}}{\partial z}\right)= \\
&\left(P\left(m_{1}+e_{1}\right)+Z e_{2}+D \delta_{1}\right)-\mathrm{DON}_{2}
\end{aligned}
$$

$\mathrm{NH}_{4}{ }^{+}$:

(A8) $\frac{\partial \mathrm{NH}_{4}}{\partial t}-\frac{\partial}{\partial z}\left(v_{\mathrm{t}} \frac{\partial \mathrm{NH}_{4}}{\partial z}\right)=\mathrm{DON} \delta_{2}-P \mu_{\left({\left.\mathrm{PAR}, \mathrm{NH}_{4}, T\right)}\right.}$
$\mathrm{NO}_{3}{ }^{-}$:

$$
\frac{\partial \mathrm{NO}_{3}}{\partial t}-\frac{\partial}{\partial z}\left(v_{\mathrm{t}} \frac{\partial \mathrm{NO}_{3}}{\partial z}\right)=-P \mu_{\left(\mathrm{PAR}, \mathrm{NO}_{3}, T\right)}
$$

Equations for sulfur cycling (DMS(P) cycle module) $\operatorname{DMSP}_{\mathrm{p}}$ :

(A10) $\frac{\partial \mathrm{DMSP}_{\mathrm{p}}}{\partial t}-\frac{\partial}{\partial z}\left(v_{\mathrm{t}} \frac{\partial \mathrm{DMSP}_{\mathrm{p}}}{\partial z}\right)=\frac{\partial\left(P q_{2}\right)}{\partial t}$

$\operatorname{DMSP}_{\mathrm{d}}$ :

(A11)

$$
\begin{aligned}
& \frac{\partial \mathrm{DMSP}_{\mathrm{d}}}{\partial t}-\frac{\partial}{\partial z}\left(v_{\mathrm{t}} \frac{\partial \mathrm{DMSP}_{\mathrm{d}}}{\partial z}\right)= \\
&\left(P\left(m_{1}+e_{1}\right)+Z g_{(P, T)}\right) q_{2}-\mathrm{DMSP}_{\mathrm{d}} \delta_{3}
\end{aligned}
$$


DMS:

(A12) $\frac{\partial \mathrm{DMS}}{\partial t}-\frac{\partial}{\partial z}\left(v_{\mathrm{t}} \frac{\partial \mathrm{DMS}}{\partial z}\right)=$

$$
\operatorname{DMSP}_{\mathrm{d}} \delta_{3} \gamma-\operatorname{DMS}\left(\phi_{z}+\delta_{4}\right)
$$

Photolysis $\left(\phi_{z}\right)$ follows the irradiance extinction profile (Kieber et al. 1996).
At the surface level of the model, the sea to air flux of DMS added to the sink terms is controlled by the transfert velocity $k w$ calculated following Wanninkhof (1992) as follows:

(A13) $F_{\mathrm{DMS}}=k_{w}$ DMS. 